\title{
TAXES, ECONOMIC CONDITIONS AND RECENT TRENDS IN MALE SELF-EMPLOYMENT: A CANADA-U.S. COMPARISON
}

\author{
Herb J. Schuetze ${ }^{* \dagger}$ \\ Department of Economics \\ Dartmouth College
}

\begin{abstract}
:
North American workers have increasingly turned to self-employment since the 1970's. Using microdata for the period 1983-1994 from Canada and the United States I assess the importance of macroeconomic conditions and the tax environment in explaining the trends in male self-employment in these two countries. My findings suggest that higher income tax and unemployment rates are associated with an increase in the rates of self-employment among North American men. Changes in the tax environment account for a considerable amount of the secular trends in male self-employment over this period, while changing economic conditions played a smaller role in determining these trends.
\end{abstract}

JEL Classification Codes: J0, J4, H24

Key Words: self-employment, income-tax, economic conditions

\footnotetext{
*Dartmouth College, 6106 Rockefeller Center, Hanover, NH 03755, phone: (603) 646-2533, fax: (603) 646-2122, e-mail: herbert.schuetze@dartmouth.edu

${ }^{\dagger}$ The author would like to thank Peter Kuhn, Lonnie Magee and Les Robb for their guidance and helpful comments in developing this work. I would also like to acknowledge the contributions of Mike Sheridan and the Surveys Branch of Statistics Canada for providing additional information on the self-employed in Canada and the National Bureau of Economic Research (NBER) for the use of TAXSIM. Support from the Canadian International Labor Network (CILN) is also greatly appreciated.
} 


\section{(1) Introduction}

The resurgence of self-employment in the United States has recently attracted the attention of a number of researchers (e.g. Blau 1987; Evans and Leighton 1989; Devine 1993). Attempts to explain this phenomenon have however met with only limited success, for a number of reasons. First, standard shift-share analyses tend to show that the factors most commonly invoked to explain this trend --industrial restructuring, and shifts in the demographic composition of the workforce-typically can account for only a small fraction of the observed changes. Second, another commonlyinvoked explanation --changes in technology-- remains very difficult to test, and in practice is often simply treated as a label attached to otherwise unattributable changes.

Finally, although this is not typically noted in the literature, there is a third reason to be skeptical of structural and technological explanations of rising self-employment: recent trends in self-employment rates are far from uniform across developed countries (OECD 1992). Indeed, with declines almost as common as increases across OECD countries, international statistics strongly suggest that country- or region- specific factors, rather than widely-shared trends like cheaper computing power, feminization of the labor force, or the move to a service economy, may play central roles in the evolution of self-employment rates.

The goal of this paper is to examine the role of two less commonly analyzed factors which do vary across regions and countries --macroeconomic conditions and the income tax environment-in explaining recent self-employment trends. Macroeconomic conditions have often been cited as a potential contributor to self-employment, especially to the extent that self-employment is used by some individuals as a "job" of last resort in poor labor markets (Quinn 1980, Becker 1984, and Bishop 1987). Tax policy, and especially the rate of personal income tax, have also been cited (e.g. 
Long 1982, Blau 1987 and Devine and Mlakar 1993) as possible determinants of self-employment rates, largely because self-employment offers individuals greater opportunity to shelter, or hide, income from tax authorities, an option which is especially valuable in high-tax jurisdictions. Clearly, if macroeconomic conditions and tax policy, rather than fundamental technological change, are driving recent increases in self-employment in some countries, policy prescriptions may differ.

Because of their focus on data from a single country and, in some cases their lack of regional disaggregation, previous authors have been limited in their ability to isolate the importance of tax and macroeconomic factors: essentially they are restricted to using a single time series of tax and macroeconomic variables. In the current paper I address this problem in two ways. First, I use 10 years of microdata covering the 12-year period 1983-1994 from two countries, Canada and the US, which are perhaps more similar in overall institutional structure than any other two countries, but which differ substantially in their income tax policy, macroeconomic conditions, and selfemployment trends. Second, I disaggregate each country's labor markets and tax jurisdictions to the state/province level, allowing me to use asynchronous variation in these conditions across these 60 provinces and states as a source of identification. In effect, my analysis operates on a pooled sample of all employed individuals in two countries over 12 years, assessing the importance of the total tax and macroeconomic environment of their province or state as a determinant of selfemployment trends. My focus in this paper is on self-employment among males aged 25-64; unlike women, men were not affected by a massive secular rise in wages, experience and overall labor force participation rates which could obscure the effects of the tax and macroeconomic factors that are the subject of this paper. Men in this age group are also less affected by secular increases in school

\footnotetext{
${ }^{1}$ Data pertaining to the years 1984 and 1985 were not available. There was no 1984 Canadian Survey of Consumer Finances and information on incorporated self-employed was not available for 1985 in Canada.
} 
attendance, a trend which plays an important role for other age groups.

My main findings are as follows. First, perhaps surprisingly, non-primary self-employment rates (hereafter simply referred to as self-employment rates) for males aged 25-64 were higher in Canada than the US during the period 1983-1994, which is the focus of my analysis. ${ }^{2}$ Second, while much has been made of an earlier increase in US male self-employment, and of the continuing increase in female self-employment, the self-employment rate of prime-age males actually fell over the period covered by my data, from 13.9 percent in 1983 to 12.4 percent in 1994 . Third, in contrast, Canada experienced an increase in male self-employment over this period, from 16.3 to 18.5 percent of the employed labor force. While certainly not conclusive, these trends and levels are strongly suggestive of both macroeconomic and tax explanations, because Canada had increasing income tax rates and a deteriorating macroeconomic environment relative to the US over this period.

Fourth, in a regression context that controls for province/state effects and industry specific time trends, I find that increases in average income tax rates have large and positive effects on the rate of male self-employment, as expected. This effect is larger using average tax rates at higher points in the income distribution, as well as for individuals with higher education levels and among those in industries characterized by "informal suppliers," who should be more affected by these tax rates. Overall, the estimated impact of a 30 percent increase in taxes is a corresponding rise in the rate of male self-employment of between 0.9 and 2 percentage points in Canada and between 0.8 and 1.4 percentage points in the US, over 1994 levels. This implies that under-reporting of selfemployment income is one of the motivating factors for becoming self-employed. In fact, a

\footnotetext{
${ }^{2}$ The rate of non-primary self-employment is the fraction of individuals employed in non-primary industries who are self-employed in their main job in either incorporated or unincorporated businesses. "Primary" industries consist of agriculture, forestry, fisheries and mining.
} 
decomposition demonstrates that changes in the average tax rates are the largest contributing factor, of the determinants examined, for the secular trends in male self-employment in North America.

Finally, increases in the provincial/state unemployment rates appear to also be associated with a rise in the rate of male self-employment. However, estimates of the elasticity of selfemployment with respect to the unemployment rate are considerably smaller than those associated with the tax rates. For instance, a 30 percent rise in the rate of unemployment in Canada (3 percentage points) would result in a 0.6 percentage point increase in the rate of self-employment using 1994 figures. While one might not expect these "macroeconomic" effects to play a large role in explaining secular changes in self-employment rates, I find that, because of the widening CanadaUS unemployment rate gap over the period examined here, they do play some role in explaining the widening Canada-US gap in self-employment. However, this role is much smaller than that attributed by my model to the tax policy variables.

The remainder of this paper is organized as follows: Section 2 summarizes recent international trends in self-employment rates, and Section 3 reviews previous explanations of trends in self-employment. The data are described in Section 4. Section 5 describes the characteristics of self-employed males and the aggregate trends in male self-employment rates, tax liabilities and unemployment rates. In Section 6 I describe and analyze the results of various regression specifications. Section 7 presents the results of a simple decomposition of the predicted male selfemployment rates between 1983 and 1992 and Section 8 concludes.

\section{(2) Recent Self-Employment Trends Across Countries}

To place the analysis of the current paper into a broader context, Table 1 gives the change 
in the rate of self-employment ${ }^{3}$ between 1973 and 1990 and the 1990 level for a number of developed countries. The nonagricultural self-employed made up over 10 percent of the employed population in half of the countries in Table 1. The highest rates of self-employment are found in Italy, Portugal, and Spain. In contrast, relatively few of the employed in Austria and Norway were self-employed. Rates of self-employment in these countries were just above the 6 percent mark.

There is also a great deal of variation in the aggregate self-employment/labor market trends in these countries. For instance, unlike Canada and the United States, eight of the sixteen countries included in Table 1 experienced a decrease in the rate of self-employment between 1973 and 1990. Of the eight countries that had a decrease in the rate of self-employment, Austria and Luxembourg witnessed the greatest declines. Self-employment rates fell in Austria and Luxembourg by 5.3 and 4.0 percentage points, respectively. Between the same years, the rate of self-employment increased by 5.8 and 4.3 percentage points in Portugal and the United Kingdom, respectively. The fact that these developed countries' self-employment experiences were so different suggests that no overriding factor, common across these countries, like technological change or industrial restructuring, is responsible for the trends in self-employment, and directs my attention toward institutional and other factors that vary across these countries.

\section{(3) Previous Studies of Self-Employment Trends}

One common explanation examined in the literature and expressed in the popular press suggests that technological advances have increased opportunities for self-employment. The dissemination of personal computers is often cited as an example of a technological change that

\footnotetext{
${ }^{3}$ The data sample and self-employment rate definition in Table 1 differ from those in the main body of the paper. Here, the sample includes both men and women and excludes the incorporated self-employed and the rate of self-employment is defined over the total population rather than the number employed.
} 
facilitates self-employment by decreasing capital costs, thereby reducing barriers to entry. Devine and Mlakar (1993) used the price of computing power to estimate the effects of technological advances on the probability of becoming self-employed both across and within industries using a series of Current Population Surveys from 1975 to 1990. They found that, across industries, the price of computing power had little or no effect on the probability of self-employment and that it had a significant positive effect within only one of the industries. Their analysis is however severely limited by use of a single computing power price series in all industries.

Another common explanation examined by researchers, related to technological change, suggests that shifts in the composition of industries' employment shares toward industries where self-employment is more prevalent can account for the rise in self-employment in North America. The most common example given is the recent shift toward service producing industries, in which self-employment has always been more prevalent, in North America. Blau (1987) and Devine (1993) tested this hypothesis using US data on males only in the former case and on both males and females in the latter case. Both papers found inter-industry shifts in employment to be a significant factor in explaining the increase in the US self-employment rate. However, as Devine points out, these shifts are not the largest contributors. Devine found that within-industry increases in selfemployment produced most of the movement in the self-employment rate.

Perhaps the most frequent explanation for the rise in self-employment given by researchers concerns shifts in the demographic composition of the workforce. The hypothesis generally put forth is that the increase in self-employment is a result of increased representation among the employed of demographic groups that have always been more likely to be self-employed. The demographics examined include age, education, marital status and gender. Typically, researchers 
have found that in a single cross section older, more highly educated, married male workers are more likely to be self-employed. ${ }^{4}$ However, changes in the demographic composition of the employed accounted for only a small fraction of the overall increase in self-employment. Moreover, the researchers found that most of the increase in self-employment occurred within demographic groups.

Most analysts pay little attention to institutional factors in their accounts of the recent trends in self-employment. Besides income tax policy, institutional factors that have been examined include minimum wage legislation (Blau 1987), immigration policy (Borjas and Bronars 1989), and retirement policies (Quinn 1980, Parnes and Less 1985, and Iams 1987). Studies of the effects of income tax policies on self-employment include Long (1982), who identified a statistically significant positive relation between imputed federal income tax liabilities and male selfemployment using a single cross section of data from the 1970 US census. Time series studies include Blau (1987), who found that only the higher of the two assumed marginal tax rates included in his study had a positive effect on the male rate of self-employment in the US between 1948 and 1982. One serious concern with this analysis is due to the lack of variation in the tax rates. Variation in the tax variables is limited to that which is captured in a time series for a single country which amounts to 35 observations-- one for each year from 1948-1982. ${ }^{5}$ A more recent study by

\footnotetext{
${ }^{4}$ See, for example, Devine (1993), Evans and Leighton (1989) and Crompton (1993).

${ }^{5}$ To illustrate this point a I did a number of variance decompositions using the data described later in this paper. A decomposition of the variance in the tax and unemployment rates within Canada and the US showed that most of the variation is explained by province or state as opposed to year. Within Canada, provincial variation in the median tax rates explained $77 \%$ of the total sum of squares while year explained $19 \%$ and the remaining $4 \%$ was unexplained by province or year indicators. These results were similar looking at tax rates in the US and for a comparable variance decomposition of the unemployment rates within the two countries. In addition, there appears that significant variation in these variables is gained by pooling the data. A decomposition of the pooled data shows that asynchronous variation in the time trends accounts for a significant portion of the total variation in the pooled data.
} 
Devine and Mlakar (1993) reported that while aggregate personal income tax rates had a positive and significant effect across industries between 1975 and 1990, within industries the same aggregate tax measure was significant only in the trade industry. Like the previous study, this study also lacks cross-section and cross-country variation in the tax measures.

A number of studies have also examined the cyclical aspects of self-employment. Again, the results are mixed. For instance, Becker (1984) observed that, in raw data, the rate of selfemployment moved counter cyclically in the US between 1948 and 1982. Using panel data on the US between 1968 and 1987, Evans and Leighton(1989) found that white men who are unemployed are almost twice as likely as employed wage workers to enter self-employment. However, they do not use this rather strong finding to explain secular trends in US self-employment. In contrast, Blanchflower and Oswald (1990) find the rate of self-employment to be procyclical using recent data on the United Kingdom. While this is one of only two papers, to my knowledge, to use regional variation in macroeconomic conditions, there were relatively few regions from a single country and the sample size in any year and region was small. A second study which also utilizes regional variation in macroeconomic conditions using Canadian data (Lin et. al 1998) finds an empirically small procyclical relationship between aggregate self-employment rates and macroeconomic conditions. One limitation of this paper is the fact that regional variation in unemployment rates comes solely from provinces whose tax rates are linked to a great extent ${ }^{6}$. The focus in Lin et. al is on determining if an aggregate cyclical relationship exists between self-employment and demand conditions unlike the current study which focuses on microdata and the effects of demand conditions

\footnotetext{
${ }^{6}$ With the exception of Quebec, provincial tax rates are calculated as a percentage of the basic federal tax liability.
} 
on secular changes in self-employment.

\section{(4) Data}

As noted above, this paper uses a series of microdata files from Canada and the US for the years 1983 to $1994^{7}$. The microdata files are taken from the Canadian Surveys of Consumer Finances $^{8}$ (SCF) and the US Current Population Surveys (CPS) which are conducted in April and March of each year and contain information on income as well as personal and labor-related characteristics for approximately 75 and 160 thousand individuals per year, respectively. Both the April SCF and the March CPS provide standard monthly labor force data as well as supplemental data on the previous year's work experience and income. The data extracted from these data files was, in some cases, recoded to make variables as consistent as possible both across years within surveys and across the surveys. All samples are restricted to males aged 25 to 64 who were employed ${ }^{9}$ in non-primary industries. The individual year/country data files are pooled to create a single data file containing 487,062 observations or approximately 49,000 observations per year of which about 32,000 observations are from the US CPS and 17,000 are from the Canadian SCF.

The variables used to identify whether or not an individual was self-employed in the two surveys were quite similar. In both surveys, respondents were asked to report whether, in their "main" job, they were i) a paid worker in the private sector, ii) a paid worker in the public sector,

\footnotetext{
${ }^{7}$ Because, unlike the CPS, the SCF data employ questions from the Labor Force Survey which refer to the "reference week" (see below) the data files used for Canada involve 1983 to 1994 labor force behaviour but the 1982 to 1993 income years. As explained earlier, 1984 and 1985 are not available.

${ }^{8}$ Additional information to that provided in the public use SCF data files was provided by Statistics Canada. The added information allows a distinction to be made between wage and salary earners and the incorporated selfemployed, who are typically grouped together. Because of a trend toward incorporation among the self-employed the true trends are typically masked.

${ }^{9}$ The data is restricted to those who were employed in the reference week in Canada and at any time in the reference year in the US.
} 
iii) self-employed in an incorporated business, iv) self-employed in an unincorporated business or v) an unpaid family worker (the exact questions are included in section A of the appendix). However, information this detailed is only available for the survey week in the SCF and for the calendar year preceding the survey week in the CPS. The incorporated self-employed are grouped together with paid employees in the CPS for the survey week and no similar question is asked for the previous year in the SCF. Because of a trend toward incorporation over this period the decision was made to use the information on both the incorporated and unincorporated self-employed in both surveys. Therefore, in the SCF, worker classification refers to the individual's main job in the week prior to the survey while in the CPS worker classification refers to the individual's longest job in the previous year.

This raises a couple of concerns. First, there may be differences between the selfemployment rates across these slightly different definitions. ${ }^{10}$ However, comparing the rates of selfemployment among unincorporated businesses based on the survey week and the previous year for a number of years from the US CPS suggests that these differences are very small (less than half of one percentage point). Second, while unlikely given the correlation between the two definitions, the determinants of self-employment may depend on the definition that is used. However, the bias in the results because of the trends in incorporation status is likely to be more of a cause for concern than the bias due to definitional differences. Therefore, the decision was made to include both the unincorporated and incorporated self-employed recognizing that the differences in definitions may

\footnotetext{
${ }^{10}$ The definition based on the survey week is at a point in time whereas the one based on the survey year requires that the individual be mostly self-employed in the previous year. Since those who are employed throughout the year but self-employed for a short term are more likely to be included in the definition based on the survey week the rate might be higher using that measure. On the other hand, we are more likely to observe individuals who had short spells of self-employment but were not employed for the remainder of the year in the survey year.
} 
not be ideal.

Because individual income tax liabilities or tax rates are endogenous in a self-employment equation, I use an alternative measure of taxes as a proxy for the "tax environment."11 The criteria for choosing such a measure are that it should (1) capture changes in the tax code over time rather than fluctuations in income, but also, (2) be rich enough to encompass variation in the tax code across the income distribution. To this end, the tax data are calculated by evaluating the income tax liability of a family ${ }^{12}$ with constant real income over the period at different points in the income distribution for each year and province/state. This is done by first calculating real family income ${ }^{13}$ at the 50th and 90th percentiles ${ }^{14}$ in each year and taking the average over the period for the two points in the income distribution. For Canada this procedure yielded figures of $\$ 49,965$ and $\$ 84,365$ real 1992 Canadian dollars for the 50th and 90th percentiles, respectively. Similar figures for the US were $\$ 51,222$ and $\$ 96,105$ in real 1992 Canadian dollars. These real income figures, one per country for each of the two points in the income distribution, are used to calculate tax liabilities within countries throughout the period. This ensures that the tax measure captures variation in tax liabilities that is due to changes in the tax code and not to tax increases that are due to fluctuations in average incomes. Separate calculations of the 50th and 90th percentiles of family income were

\footnotetext{
${ }^{11}$ An alternative to "proxying" for the tax environment would be estimate using two-stage least squares including the proxy variable as an instrument for actual tax outcomes. However, data on actual tax outcomes is not available in the CPS, though it is in the SCF.

${ }^{12}$ The term "family" refers to a couple (male and female) with no children. Children were not considered here for the sake of simplicity.

${ }^{13}$ Family income is calculated by ranking family income (as defined in the survey) for males and taking the male's income associated with family income at the 50th and 90th percentiles. A similar procedure yields female incomes associated with family incomes at the 50th and 90th percentiles. The male income and female incomes are added together to create a "family" (couple) for the 50th and 90th percentiles.

${ }^{14}$ Initially, the 10th percentile was also used. However, because of data limitations that prevent me from calculating tax credits and deductions available to low-income families in Canada the 10th percentile was dropped.
} 
computed for each country because tax codes are linked to a great extent to a country's income level and income distribution. Using the nominal equivalent of the real incomes for the two points in the income distribution, tax liabilities net of deductions for each year and province/state are then calculated using information taken from a series of publications from the Canadian Tax Foundation, for Canada, and using the computer program TAXSIM ${ }^{15}$ from the National Bureau of Economic Research for the US (for details on the deductions etc. included in the tax calculations see section B of the appendix). For estimation purposes the combined real federal and provincial/state tax liabilities for each province/state and year are used. US figures are converted to real 1992 dollars using the US consumer price index and then to real Canadian 1992 dollars using the purchasing power parity figure ${ }^{16}$ for that year. All tax liabilities are converted to an average ${ }^{17}$ tax rate by dividing by the relevant real income used in calculating the liabilities.

Average unemployment rates are calculated for males and females together by province or state using the SCF and CPS microdata files. Aggregate average annual unemployment rates are used as regressors since they are less likely to be endogenous than male unemployment rates alone.

\section{(5) Sample Characteristics and Trends}

\section{Sample Characteristics}

Table 2 presents raw self-employment rates and the employment shares by demographic group and industry category in Canada and the US, separately, for 1983 and 1992 (two years at

\footnotetext{
${ }^{15}$ For Canada see the Canadian Tax Foundation publications (1982-1993) and for information Regarding Taxsim see: Feenberg et al. (1993).

${ }^{16}$ Purchasing power parity figures are taken from the PENN World Tables (version 5.6).

${ }^{17}$ The average rate is used rather than the marginal rate in part because I am considering discrete changes rather than marginal changes in labor market activities (i.e. whether or not an individual is self-employed in his main job). The individual takes into account the "overall" tax burden. In practice, average and marginal tax rates are likely to be highly correlated across time and space.
} 
similar points in the business cycle ${ }^{18}$ ). The employment shares are the percentages of the samples (the employed) in each group or cell and sum to one hundred over the demographic and industry groupings in any year and country.

Two opposing shifts in the age structure of employed males in Canada and the US occurred between 1983 and 1992. The first, which is doubtless the result of the "baby boom," is an increase in the age of the male working population. Employment shares among the lowest age category fell while these same shares rose or remained constant for those age 36-55. Since male selfemployment rates tend to increase with age this shift favours increased self-employment. However, a second shift-- likely caused by a trend toward early retirement in North America-- acted at the same time to decrease employment shares among the oldest workers in the sample (those aged 5564). The expected effect of the two shifts on self-employment, therefore, is indeterminate.

One interesting characteristic of the self-employment rates across education categories found in Canada but not in the US is the "U-shaped" pattern of self-employment rates. In Canada, the raw self-employment rates are highest in the lowest education category (those with 8 or less years of education). ${ }^{19}$ Male self-employment rates fall with education beyond 8 years in Canada but increase slightly for those with any post secondary education relative to those with 11-13 years of education. In the US, unlike in Canada, male self-employment rates tend to increase monotonically with the level of education. Between 1983 and 1992 the level of education among employed males in both Canada and the US increased. This shift toward more highly educated workers clearly favours

\footnotetext{
${ }^{18}$ Both 1983 and 1992 were relative troughs in the business cycle (i.e. years in which the unemployment rate reached a local maximum) in Canada and the US

${ }^{19}$ Interestingly, in almost all industry and occupation categories the rate of self-employment among loweducated workers in Canada is higher than in the US.
} 
increased self-employment in the US but because of the non-monotonic relationship between selfemployment rates and education in Canada it is not clear whether or not such a shift has the same effect in that country.

Shifts in the family structure of employed males between the two years, for the most part, worked against increased self-employment. Fewer employed males were married-- the group with the highest self-employment rates-- and more workers were single and divorced, widowed or separated in 1992 relative to 1983 . The share of male workers in Canada and the US with no older children (aged 7-17) increased between 1983 and 1992. This shift should act to decrease selfemployment rates because, unlike for the presence of young children, male self-employment rates tend to rise with the number of older children present in the family in both countries.

Employment shares among North American males shifted toward industries in which male self-employment rates were high. Rates of self-employment in Canada and the US were highest in the construction, services and retail trade industries and lowest among the manufacturing industries. Between 1983 and 1992 employment shares fell substantially in the manufacturing industries in both countries and rose in the service industries and, to a certain extent, in the retail trade and construction industries as well.

It appears from the raw data, therefore, that in both countries, some shifts in the demographic and industrial structure of the employed favored self-employment, while others worked against it. This casts some doubt on the potential of explanations for the trends in self-employment based on such shifts. Also incompatible with such an explanation is the fact that, in Canada, where aggregate self-employment rose between 1983 and 1992, the rate of self-employment rose within all demographic groups except for single males and within all industries except manufacturing 
durables and retail trade.

\section{Self-Employment Rate Trends}

Figure 1 shows the trends in the non-primary self-employment rates for males aged 25 to 64 for Canada and the US over the period. The rate of male self-employment in Canada lies everywhere above the US rate throughout the period. Between 1983 and 1989, the rates of male self-employment in both countries were relatively stable. In Canada, this rate fluctuates by less than one percentage point and closes out the period at about the same rate (16.3 percent) that it was in 1983. Similarly, in the US this rate was constant, hovering around the 13.5 percent mark - starting out slightly above this mark at 13.9 percent in 1983 and ending up slightly below at 13.1 percent in 1989. Following 1989, however, the Canadian and US male self-employment rates diverge. In Canada it rises from 16.2 percent in 1989 to 18.7 percent in 1993 and then falls slightly in 1994. In the US, on the other hand, this rate remains stable up until 1992 and then declines by about one percentage point from 1992 to 1994 . The gap between the rates in Canada and the US, which averaged about 3 percentage points between 1983 and 1989, doubled by 1994 to just over 6 percentage points.

Figure 2 disaggregates the country-specific annual self-employment rates by incorporation status. In both Canada and the United States the number of unincorporated self-employed outnumbers the incorporated self-employed over the entire period. The fractions of workers employed in unincorporated businesses in Canada and the US were about the same until 1990, when the Canadian rate rose relative to the US rate. Prior to 1990, the unincorporated self-employment rate in both countries was about 9 percent. After 1990, this rate rose to almost 11 percent in Canada and fell to 8 percent in the US by 1994 . One striking difference between the two countries is the 
large gap between their rates of self-employment in incorporated businesses,${ }^{20}$ which is roughly constant over the period.

\section{$\underline{\text { Average Tax Rates }}$}

The trends in tax rates, like those in the self-employment rates, diverged significantly between Canada and the US over the period. ${ }^{21}$ Figures 3 and 4 show the average annual tax rates for the two countries separately $y^{22}$ for a family earning the median and 90th percentile of income, respectively. In Canada, at both income levels, tax rates rose throughout the period with the exception of a sharp decline between 1987 and 1988. This was a result of tax reform which resulted in a reduction in tax rates and a change in the rate schedule from 10 tax brackets to only 3 brackets. The greatest rise in average tax rates occurred in Canada between 1983 and 1987 among families earning median income. Over the entire period, average tax rates in Canada rose by 1.5 percentage points for median income families and 2 percentage points for families at the 90th percentile. Between 1982 and 1987 tax rates in the US fell by 4.5 percentage points for median family income earners. The downward trend in tax liabilities continued an extra year for US families at the 90th percentile which resulted in a decline of almost 7 percentage points between 1982 and 1988. Tax rates were stable for median US family income earners following 1987 and for those at the 90th percentile following 1988.

\footnotetext{
${ }^{20}$ The rates of self-employment in incorporated businesses are higher in Canada than the US in all industries. The rates in Canada are about twice those in the US in all industries over the entire period except for construction where the rate is about four times higher in Canada. One would expect to find rates higher in a single industry if these differences were definitional (e.g. if lawyers were considered self-employed in Canada but not in the US).

${ }^{21}$ Throughout the analysis I examine the effects of lagged taxes on current self-employment rates for reasons which will become obvious. For consistency and because tax data for the US in 1994 are not currently available the trends from 1982-1993 are examined here.

${ }^{22}$ Average annual tax rates at the country level are calculated as a weighted average of the provincial or state level rates using the sample weights.
} 
Figures 5 and 6 present the average tax rates for a family earning median income for six provinces and six states, respectively, over the period examined. The provinces or states were chosen to illustrate the variation in the regional tax rates. In all cases, the provinces or states with the highest and lowest average tax rates over the period are included in the figures. Average tax rates for a family at the median in Canada (Figure 5) were highest in Quebec and lowest in Alberta. The provincial trends, which for the most part followed a similar time path, contained some crossprovince variation. For instance, between 1982 and 1987 average tax rates rose by 1.7 percentage points in Quebec and by almost twice that figure in Alberta: rising by 3.3 percentage points. Further, the rather sharp decline in tax rates, experienced to varying degrees in all the provinces between 1987 and 1988, was more than twice as large in Quebec as in Manitoba. Average tax rates fell by 1.8 and 0.7 percentage points in Quebec and Manitoba, respectively.

In the US, the dispersion of average tax rates for a family at the median in any given year was much larger than in Canada. The difference between the highest (New York) and lowest (Florida) tax rate by state in the US (Figure 6) was on average 10 percentage points over the period. The state trends, like the provincial trends, followed similar time paths, however, there was a great deal more asynchronicity in the variation of tax rates in the US than in Canada. For example, average tax rates in Arkansas fell by almost 5 percentage points between 1990 and 1991 and rose by 4 percentage points in North Dakota between 1991 and 1992. These tax rate variations came at a time when the other state tax rates were stable.

\section{Unemployment Rates}

Figure 7 shows the aggregate unemployment rates for individuals aged 15 and over in Canada and 16 and over in the US between 1983 and 1994. A gap which opened up in the early 
1980's between the Canada and US unemployment rates persists throughout the period. The Canadian unemployment rate increased from about 2 percentage points above the US rate in the 1980 's to 3.5 percentage points above it in the 1990's. In both countries the unemployment rate falls between 1983 and 1989, rises between 1989 and 1992 and falls again after 1992.

Like the trends in average tax rates by province or state, unemployment rates by province/state follow somewhat similar time trends in Canada and the US. However, as Figures 8 and 9 show there is greater regional variation in the time trends for unemployment rates than for average tax rates. In Canada and particularly in the US there are numerous examples where one province or state is experiencing a decline (rise) in its unemployment rate while the other provinces/states are experiencing a rise (decline) in unemployment rates. Further, provincial/ state unemployment rates, even when rising or falling together, do so to varying degrees.

\section{(6) Estimation and Results}

An empirical investigation into the role that average tax rates and economic conditions play in the decision of males to become self-employed proceeds by estimating a linear probability model by $\mathrm{OLS}^{23}$ using the pooled cross-section time-series data on Canada and the US combined with the province/state level tax and unemployment data described above. The data file contains more than 487,000 observations on ten years between 1983-1994 resulting in an average of 49,000 observations a year.

Separate regressions are estimated using the average tax rates for a family with the median

\footnotetext{
${ }^{23}$ OLS was used rather than a probit because of the difficulties that arise performing decompositions with a non-linear model. In any case, work not reported here showed that the coefficients/results are similar to the OLS results when a probit is used to estimate the "base" model.
} 
and 90th percentile incomes ${ }^{24}$ for the following model $^{25}$ :

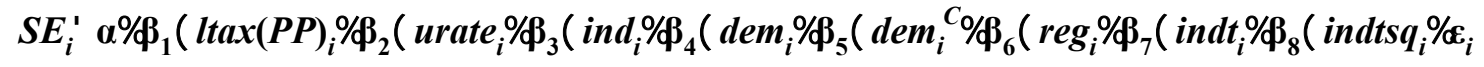

$\boldsymbol{\alpha}, \boldsymbol{\beta}_{1}$ and $\boldsymbol{\beta}_{2}$ are scalars while the remainder of the coefficients are vectors. Subscript "i" indexes each of the individual observations ( 1 to 487,062 ) and the tax and unemployment rate apply to the year-province/state in which individual i lives. SE is a 0-1 indicator variable for self-employment, equal to 1 if the individual is self-employed. $\operatorname{Itax}(\mathbf{P P})$ is the lagged average tax rate where PP is the two digit percentile (50 or 90$)^{26}$ and urate is the current year's unemployment rate. ${ }^{27}$ ind is a series of industry dummy variables, $\mathbf{d e m}$ and $\mathbf{d e m}^{\mathrm{C}}$ are a number of demographic variables and those same demographic variables crossed with a country dummy (equal to 1 if the country is Canada and 0 if the US), respectively, and reg is a set of dummy variables for individual province or state. Indt and indtsq are the industry dummies crossed with a linear time trend and a linear time trend squared, respectively. One might expect that differences in industry composition would explain much of the difference between self-employment rates in Canada and the US. For this reason, the controls for industry fixed effects as well as time-varying industry characteristics, such as industry-specific

\footnotetext{
${ }^{24}$ The decision was made to include the tax rates from different points in the income distribution in separate regressions rather than including both in a single regression because the two measures are highly correlated. By comparing the results of the separate regression this approach accounts for sensitivity in the model to non-linearity in the tax code.

${ }^{25}$ For a complete description of the variables see appendix, section C.

${ }^{26}$ Ideally one would like to include both personal and business taxes in equation (1) because both tax codes influence the self-employment decision. However, personal tax codes are essentially the same as those for selfemployed individuals in unincorporated businesses with the exception that more tax deductions are available to the self-employed. Also, under certain circumstances the tax structure for the incorporated self-employed is the same as that for personal income tax. Therefore, I feel that the costs of including such data outweigh the benefits.

${ }^{27}$ The current tax rate and the lagged unemployment rate were statistically insignificant when the lagged tax rate and the current unemployment rate are included in the regression (see Table A1). This result seems reasonable given that individuals really might not understand the full impact of a tax change until they do their taxes the following year or might not need to react to these increases immediately, but unemployment will have an immediate impact on an individual's labor market activities.
} 
technological change, are included.

The estimation results using both the median and 90th percentile tax rates for equation (1) are presented in Table 3. Column two of the table shows the estimated coefficients and the standard errors $^{28}$ using the tax rates at the 50th percentile and column three gives similar results for the tax rates calculated at the 90th percentile. In both regressions the coefficients on the average tax rates are positive and significantly different from zero at standard levels. However, the impact of an increase in the average tax rate at the 90th percentile on the probability of becoming self-employed is larger than the impact from the same tax increase (in percentage terms) at the median. The elasticities of male self-employment with respect to the average income tax rates at the median and 90th percentile using 1994 figures in Canada are 0.16 and 0.30, respectively. These same elasticities using US data are slightly larger at 0.21 and 0.37 . These elasticities mean that a 30 percent increase in taxes in 1994 would lead to an increase in the rate of male self-employment in Canada of 4.8 percent or 0.9 percentage points using average tax rates at the median and 9 percent or 2 percentage points using taxes at the 90th percentile. Similar estimates using US data are 6.3 percent or 0.8 percentage points using taxes at the median and 11.1 percent or 1.4 percentage points using taxes at the 90th percentile. To put such a tax increase into perspective, a 30 percent increase in family income tax is equivalent to a tax increase in 1992 Canadian dollars of $\$ 2500$ for a family at the median and $\$ 7100$ for a family at the 90th percentile in Canada or $\$ 2250$ and $\$ 6650$ in the US over

\footnotetext{
${ }^{28}$ As Moulton (1990) suggests, when a regression is fit to micro observations using both aggregate data and microdata as explanatory variables there is a possibility that the disturbances are correlated within the aggregate groups and even small correlations of this type can cause a large downward bias of the standard errors. The magnitude of the bias depends upon, among other things, the correlations of the regressors within groups. Within provinces/states in any given year in my data both the tax rates and the unemployment rates are perfectly correlated. The standard errors (in parentheses) are White's estimates with province/state-year cells as the primary sampling unit (i.e. the robust command in stata was used for clustered samples by state/year). These estimates account for this type of "group-wise" autocorrelation.
} 
1994 levels.

An increase in the unemployment rate also had a positive effect on self-employment in both regressions. However, the magnitude of the increase in self-employment resulting from an increase in the unemployment rate was smaller than that from an increase in taxes. The elasticity of selfemployment associated with the unemployment rate is equal to about 0.1 in both countries using 1994 figures. This means that a decrease of 5 percentage points in the unemployment rate (about the same decline that occurred between 1983 and 1989 in the US) leads to about a 1 percentage point decrease in the self-employment rate.

Other results shown in Table 3 are consistent with those of previous researchers. ${ }^{29}$ I find that: (1) Age has a positive effect on the probability of self-employment and the effect is similar in both countries. It might be the case that older workers have accumulated entrepreneurial abilities, savings and business links making them more likely to be self-employed. ${ }^{30}$ (2) Increases in educational attainment lead to increases in the probability of being self-employed in the United States. Unlike what is typically found in studies on US males, increases in education had almost no effect on the probability of being self-employed for Canadian males. (3) The more children present in the family the more likely males were to be self-employed. This fact was particularly true if the children were younger-- less than age 7 . This might be because self-employment allows for greater flexibility in hours and the ability to work at home which gives workers the chance to take care of younger children. (4) Married men were most likely to be self-employed followed by men who were

\footnotetext{
${ }^{29}$ See Aronson (1991) for a review of this literature.

${ }^{30}$ Another issue dealt with in the self-employment literature related to age is the effects of retirement on self-employment. Researchers have found that retired individuals are more likely to be self-employed than nonretirees (for example, Parnes and Less 1985 and Iams 1987). To control for retirement status and the trend towards early retirement equation (1) was re-estimated for males age 25-54. Excluding older males from the sample had little effect on the parameter estimates (see appendix Table A1)
} 
divorced widowed or separated. This is probably because married men are more likely to be in a family with a second income and fringe benefits that extend coverage to the entire family. A spouse's earnings and fringe benefits provide easier access to capital and allow greater risks to be taken. (5) Though not presented in the table, males in construction trades were most likely to be self-employed followed by retail trade and service industries.

The positive and significant effects of the tax environment and economic conditions on the probability of self-employment for North American males found here are robust for different specifications. Table 4 presents coefficient estimates for the tax rates and unemployment rates using a number of different samples or specifications ${ }^{31}$. Panel A, included for comparison, presents the same coefficients and standard errors as in Table 3 using the average tax rates calculated on a family earning the median and 90th percentile of income for the sample which includes both the incorporated and unincorporated self-employed. Panel B gives similar results where only individuals who are self-employed in incorporated businesses are included in the sample while Panel C includes only those who are self-employed in unincorporated businesses. Panel D redefines which individuals in the sample are considered self-employed in an attempt to capture individuals who may be "part-time" self-employed or who are self-employed in a secondary job. Here individuals who had non-zero self-employment income from unincorporated businesses are considered selfemployed.

In almost all cases, the coefficients on the lagged average tax rate and the unemployment rate are positive and significant at the five percent level. The one exception is Panel B where only males self-employed in incorporated businesses are considered. The coefficients on both the tax and

\footnotetext{
${ }^{31} \mathrm{~A}$ complete list of variables and their associated standard errors are included in the appendix Table A2
} 
unemployment rates in Panel B are small and insignificant. The most likely explanation for this result is the fact that firms tend to start out as unincorporated firms and only incorporate as the firm grows. Thus, the link between self-employment status and the tax environment or aggregate demand is diluted. The results in Panel D suggest that tax exemptions and write offs alone, which are available to both full and part-time self-employed, are not enough of an incentive to lure some of these males into self-employment. Panel D shows that the "part-time" self-employed males are less responsive to changes in the tax environment. While still highly significant, the coefficients on the lagged average tax rates are dampened when both "full-time" and "part-time" unincorporated selfemployment status is included as the dependent variable compared to Panel C where only "full-time" self-employed in an unincorporated business are considered on the left-hand-side. Part-time selfemployment, besides allowing a number of tax write offs, does not enable individuals to underreport as large a proportion of income to tax authorities as those engaged in self-employment fulltime.

The positive relation found here between the probability of self-employment and the average tax rates is contingent upon the assumption that the industry-specific time trends are the same in both countries. $^{32}$ In other words, within industries, factors like technological change are assumed to have the same effect across the two countries, which is likely to be the case given the very strong links between the two economies of Canada and the US. This assumption, while not ideal, compares favourably to previous research on this topic. Only when fairly strict controls are introduced into

\footnotetext{
${ }^{32}$ A Hausman test of the restrictions imposed in this model by pooling the data rejects the hypothesis that the coefficients are the same in the two countries. However, a similar test for Canada and the US, separately, rejects the hypothesis that the coefficients are the same across the provinces/states within these two countries. It appears that, while useful in some contexts, the Hausman test as applied here may be overly sensitive and too stringent to provide insightful guidance. Given the similarities in the overall structure of the two economies it seams a logical progression to increase variation in the variables of interest by pooling across these countries.
} 
the model by allowing the industry-specific time trends to vary across the two countries do the coefficients on the average tax rates become small and statistically insignificant. ${ }^{33}$ However, relaxing this assumption is likely to eliminate much of the variation in the average tax rates. Controlling for within-industry time trends by country while simultaneously including controls for fixed effects across provinces/states is likely to soak up much of the variation in the tax data.

\section{Supporting Evidence}

In order to show that the positive correlation found here between the income tax rates and the probability of self-employment is not simply a spurious relationship I present two pieces of supporting evidence.

First, one might expect that individuals with greater potential productivity (higher income) would be affected more by increases in income tax rates associated with income at higher points in the income distribution than individuals with lower potential productivity. One can not determine whether or not males at the top of the income distribution are more responsive to changes in the tax rates from the results presented above because the income tax rates are taken from a single point in the income distribution and applied to males at all points in the income distribution. Therefore, to examine this relationship more closely the tax variables are interacted with education category indicators in equation (1). This method links income tax rates to productivity by using education as a proxy for productivity.

The results, which are presented in the top half of Table 5, confirm my expectation and provide additional support for the tax finding. Males in the highest education category (those with

\footnotetext{
${ }^{33}$ The coefficients and standard errors on lagged average taxes for a family earning the median and the 90 th percentile are $-.0343(.0634)$ and $.0695(.0621)$ when the industry-specific time trends are crossed with a country indicator. The standard errors correcting for group-wise autocorrelation are in parentheses.
} 
any post-secondary schooling) appear to be more responsive to changes in the tax rate at the 90th percentile. The coefficient on average income tax rates at the 90th percentile interacted with the highest education category is significantly different than zero and results in a tax effect that is more than twice the size $(0.27$ versus 0.12$)$ of those interacting the tax at the 90 th with the other education categories. An F-test on the joint significance of the tax-education interaction coefficients reveals that these coefficients are jointly significant at the 5 percent level when the tax is calculated at the 90th percentile. As we might expect, increases in educational attainment had weaker effects on the tax coefficient calculated at the median. The coefficient on the tax-education interaction terms were individually not significantly different than zero and were jointly insignificant at the 5 percent level.

Second, it is undoubtably the case that the self-employed in different industries or occupations have different abilities to avoid taxes. For instance, those proprietors whom the US Internal Revenue Service (IRS) call "informal suppliers" or "individuals who provide products or services through informal arrangements which frequently involve cash-related transactions or 'off the books' accounting practices" 34 have a greater ability to under-report income. One would expect, therefore, that the tax effect in the current study would vary in terms of magnitude across industries-with industries characterized by these "informal suppliers" having the largest coefficients.

In the bottom half of Table 5 the tax variable is crossed with industry indicator variables. The results show that the effect of the tax rate on the probability of self-employment varies significantly across industries. F-tests for the null hypothesis that the coefficients are the same are rejected at standard levels. Among the industries in which the tax effect is the largest are the retail trade, construction and transportation industries. The industries in which the tax effect was lowest

\footnotetext{
${ }^{34}$ U.S. Internal Revenue Service, 1996, p.43.
} 
include finance/insurance/real estate, manufacturing and wholesale trade.

Interestingly, the rank ordering by industry of the IRS estimates of the percentage of taxes under-reported among proprietors conform with the findings in Table 5. Under the US Taxpayer Compliance Measurement Program (TCMP) stratified random samples of income tax returns are subjected to intensive audits. A breakdown of the estimates of under-reporting by proprietors from data collected through the TCMP is provided in US General Accounting Office (1990). According to this report the industries in which the percentage of tax under-reporting was the greatest include: Retail Sales (fixed location) 39\%, Transportation 36\%, Retail Sales (no fixed location) 31\% and production (including construction). The lowest estimates of under-reporting were recorded among the wholesale trade $19 \%$, and finance/insurance/real estate $16 \%$. The remarkable similarities in ranking by industry between Table 5 and the IRS estimates provide strong evidence that the correlation found between tax rates and self-employment is not a spurious relationship.

\section{(7) Decompositions}

This section describes a simple decomposition used to determine what fraction of the overall change in predicted male self-employment rates between 1983 and $1992^{35}$ is explained by movements in average tax rates, unemployment rates and the demographic and industrial composition of the employed. Results for the decomposition are presented for the changes in the predicted self-employment rates in Canada and the US, separately, as well as for the change in the gap between the Canadian and US predicted self-employment rates that existed over this period.

One can examine aggregate predicted self-employment rates for each country separately in

\footnotetext{
${ }^{35}$ These years were chosen because both 1983 and 1992 were relative troughs in the business cycle (i.e. years in which the unemployment rate reached a local maximum) in Canada and the US. This allows me to focus on factors which best explain secular, rather than cyclical, changes in self-employment rates.
} 
any given year by averaging each of the variables in equation (1) as follows:

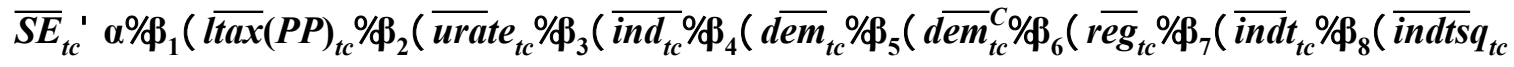

Let $t$ index the year and $c$ index the country. The $\alpha$ and $\beta$ 's are the parameter estimates from equation (1). Then, $\overline{\boldsymbol{S E}}_{\boldsymbol{t c}}$ is the predicted self-employment rate in year $\mathrm{t}$ and country c given the average characteristics of the individuals in that year and country. Also, one can define groupings of the independent variables by summing the components as follows:

$$
\overline{S E}_{t c}{ }^{\prime} \alpha \% \beta^{T}\left(\overline { X } _ { t c } ^ { T } \% \beta ^ { U } \left(\bar{X}_{t c}^{U o} / \beta^{D}\left(\bar{X}_{t c}^{D} / \beta^{I}\left(\overline { X } _ { t c } ^ { I } \% \beta ^ { U N } \left(\bar{X}_{t c}^{U N}\right.\right.\right.\right.\right.
$$

Here, the X's replace variable names. The superscripts indicate groupings of variables: $\mathrm{T}$ is the tax variable, $\mathrm{U}$ is the unemployment rate, $\mathrm{D}$ represents the demographic components including region, I represents the industry fixed effects and UN represents the industry specific time trends, which I think of as the unexplained component. ${ }^{36}$

The change in the predicted rate of self-employment in a given country between any two years $\{t, \tau\}$, for $\tau>t$, can, therefore, be written:

$$
\overline{S E}_{\tau c} \& \overline{S E}_{t c}^{\prime}\left(\bar{X}_{\tau c}^{T} \& \bar{X}_{t c}^{T}\right) \beta^{T \%} /\left(\bar{X}_{\tau c}^{U} \& \bar{X}_{t c}^{U}\right) \beta^{U \%} /\left(\bar{X}_{\tau c}^{D} \& \bar{X}_{t}^{D}\right) \beta^{D \%} /\left(\bar{X}_{\tau c}^{I} \& \bar{X}_{t c}^{I}\right) \beta^{I \%}\left(\bar{X}_{\tau c}^{U N} \& \bar{X}_{t c}^{U N}\right) \beta^{U N}
$$

Then, for example, $\frac{\left(\bar{X}_{\tau c}^{T} \& \bar{X}_{t c}^{T}\right) \beta^{T}}{\overline{S E}_{\tau c} \delta \overline{S E}_{t c}}$ is the fraction of the overall change in the predicted selfemployment rate between $\tau$ and $t$ that is explained by the change in the provincial/state average tax rates. One can calculate a similar fraction for changes in unemployment rates, demographics, and the industrial composition of the work force as well as for the unexplained portion. The fraction of the change in the gap between the Canada and the US male self-employment rates explained by each

\footnotetext{
${ }^{36}$ To the extent that technological change is industry-specific but the same on either side of the Canada-US border, these can also be thought of as representing technological change.
} 
of these components can be determined by differencing the average characteristics in equation (3) by country so that the left-hand-side of (3) becomes the Canadian male predicted self-employment rate in year $\mathrm{t}$ minus the US male predicted self-employment rate in year( $\mathrm{t}$ ).

Table 6 shows the results of the decomposition described above for Canada (Panel A), the US (Panel B) and the Canada-US gap (Panel C) for the years 1983-1992. Rather than repeating the exercise for both sets of tax calculations the decomposition results are shown for the average tax rates calculated on a family with median income only. The first column of each of the panels gives the total predicted change attributable to each of the components (e.g. $\left.\left(X_{\tau c}^{T} \& X_{t c}^{T}\right) \beta^{T}\right)$ while the second column gives the fraction of the change that is due to changes in each of the components. The lower half of the table breaks down the demographic grouping into its components. As one might expect, the model does not predict the changes in the raw self-employment rates very well. For example, the model predicts only about 35 percent of the rise in the self-employment rate that occurred in Canada between 1983 and 1992. The model is a bit better in predicting the decline in the US rate and the increase in Canada-US gap between the two years. Approximately 50 percent of the actual changes in the US rate and 45 percent of the gap are predicted by the model. However, the results useful as in ranking the explanatory power of the determinants examined.

In Canada (Panel A), changes in the provincial tax rates between 1983 and 1992 explained the largest fraction of the predicted change in male self-employment rates among the factors examined here. Changes in the average tax rates accounted for $192 \%$ of the overall change in the self-employment rate. This suggests that, holding all other factors constant, the male selfemployment rate in Canada would have increased by almost twice as much as it did between 1983 and 1992 given the changes that occurred in the provincial average tax rates. In Canada, unlike in 
the US, changes in the industrial composition of the employed also helps substantially in explaining the increase in the male self-employment rate. Changes in the unemployment rate, the demographic composition of the workforce and the unexplained portion offset the effects of the average tax rates and industry sector shifts. Each of these offsetting components would have led to a decrease in the rate of male self-employment in Canada between the two years had it been the only variable to change.

The overall fraction explained by changes in the demographic composition of the employed was negative in Canada. However, this masks some of the effects of the individual components that make up the demographic grouping. For instance, changes in the age and education structure of the employed in Canada accounted positively for the overall change in male self-employment. The positive effects of age and education were dominated by the negative effects that changes in the number of children, marital status and province of residence had on the overall rate of male selfemployment in Canada.

In the US (Panel B), as in Canada, changes in the average tax rates explained the largest fraction of the overall predicted change (in this case a decline) in the male self-employment rate between 1983 and 1992. Changes in tax rates between 1983 and 1992 in the US accounted for 199\% of the overall change in the predicted male self-employment rate. Changes in the industrial composition of workers in the US did not explain the decline in the male self-employment rate between 1983 and 1992. In fact, the results suggest that the male rate of self-employment would have increased if the only factor that changed over the period had been the composition of industries' employment shares. Unlike in Canada, changes in the unemployment rate in the US explained some (79\%) of the change in the male self-employment rate over this period. Like in Canada, changes in 
the demographic composition of the employed accounted for a negative fraction of the overall change in male self-employment. Also as in Canada, changes in age and education of the US workforce suggest that the rate of male self-employment should have risen while changes in the number of children, marital status and state led to a decline in the rate between 1983 and 1992. However, in the US the effects of shifts in age and educational attainment among the employed dominated the effects of the other demographic changes.

Finally, the decomposition is used to explain the gap between the Canada and US male selfemployment rates which widened between 1983 and 1992. The raw numbers suggest that the gap between the two countries' male self-employment rates widened by more than 1 percentage point between 1983 and 1992. The model predicts about a 0.6 percentage point increase in the gap between the two years. As with the individual country analyses, changes in the provincial/state average tax rates account for the largest fraction of the increase in the predicted gap. Changes in average tax rates account for $197 \%$ of the predicted increase in the gap between the two selfemployment rates. Changes in the unemployment rates account for a relatively small fraction (37\%) of the increase in the gap. Shifts in both the demographic and industrial employment shares of the two work forces countered the effects of the tax and unemployment rates on the Canada-US male self-employment rate gap between 1983 and 1992.

Overall, the results from the decompositions show that changes in the average tax rates consistently explain a large fraction of the predicted shifts in the Canada and US male selfemployment rates as well as the gap that opened up between the two rates from 1983 to 1992 . The role that unemployment rates played in explaining changes in the male self-employment rates is not quite as clear. In Canada economic conditions explained a negative fraction of the rise in predicted 
male self-employment while in the US economic conditions had at least some explanatory power.

In Canada, shifts in the industrial composition of the employed appears to explain a significant fraction of the increase in male self-employment while changes in the demographics of the workers did not help to explain the increase. Both composition effects did not explain any of the decline in the US rate of male self-employment nor the gap between the Canada and US rates.

\section{(8) Conclusions}

The literature on self-employment to this point has primarily focused on factors that have global effects for most developed economies. However, the evidence suggests that no single common factor is responsible for the trends. For this reason, this paper has focused on regionspecific factors-- namely the tax environment and economic conditions-- as possible causes for the trends in male self-employment in North America. This examination improves upon previous studies which have examined the effects of taxes and economic conditions on self-employment by incorporating province or state as well as cross-country variation in the tax and unemployment data. The results presented here provide evidence that changes in the tax environment explain a considerable amount of the secular trends in male self-employment in North America while economic conditions explain less of these trends.

The empirical analysis shows that even with fairly strict controls for industry characteristics, increases in average income tax rates have positive and large effects on the rate of male selfemployment. The estimated effect of increasing taxes by 30 percent is an increase in the rate of male self-employment in incorporated and unincorporated businesses of between 4.8 and 11.1 percent. This suggests that one of the motivations for becoming self-employed is the relative tax advantages associated with self-employment. In fact, the decompositions demonstrate that changes 
in average tax rates are the largest contributing factor of the possible determinants examined here for the secular trends in self-employment in Canada and the US. While previous studies by Blau (1987) and Devine and Mlakar (1993) reported some evidence of a positive relationship between tax rates and self-employment the findings were not convincing because of conflicting results. In addition, these studies did not attempt to quantify the importance of taxes as an explanation for the trends in self-employment. Indeed, by examining the effect of the tax environment on selfemployment across variously defined groups of self-employed males, this study has uncovered some of the more salient features of this relationship. The finding that the probability of self-employed in a secondary job is less responsive to increases in income taxes than the same probability in a main job implies that tax sheltering alone is not enough of an incentive to lure some North American males into self-employment. Instead, for some it is the relative ease of under-reporting income in self-employment that is the factor determining self-employment status among these males.

The results also support the notion that North American males turn to self-employment to some extent during spells of high unemployment. This result adds new evidence to the debate in the literature on whether or not individuals are being "pushed" into self-employment. It could be that individuals experiencing unemployment find this transition to be a convenient time to become self-employed or that self-employment is simply employment of last resort. It appears, however, that economic conditions had a smaller role in determining self-employment among these males than the tax environment did. Further, the unemployment rates did not explain much in terms of the secular trends in self-employment in Canada and the US over this period, as was illustrated by the decompositions.

A number of policy implications arise from these findings. First, raising income taxes may 
result in increased numbers of workers moving into the self-employment sector where their labor income can be taxed at a lower rate. This will leave fewer tax paying workers which, in turn, may require greater-than-expected increases in income taxes. Second, the fact that self-employment appears to provide employment during downturns suggests that policies that provide assistance to fledgling entrepreneurs may assist in alleviating the particularly harmful negative employment effects of recessions. Not surprisingly, however, this policy prescription should be regarded as highly tentative for a number of reasons. First, it is not clear from this analysis whether or not this finding is a result of an increase in the actual number of self-employed individuals. It could be that jobs in the self-employment sector are simply more insulated against demand shocks than wage and salary jobs. Therefore, in recessions the rate of self-employment may rise because the number selfemployed holds constant while the total number of individuals employed falls. Second, supposing that new jobs are created in the self-employment sector during recessions, we are unable to discern from this analysis how stable these newly created self-employment jobs actually are. These jobs could be temporary and, therefore, not worthy of assistance. It seems that an analysis that includes a longitudinal component would be effective in providing answers to these questions. In any case further analysis is required to sort these issues out. 


\section{TABLES}

TABLE (1)

Non-Agricultural Self-Employment, 1973-1990

Percentage Point Changes

\begin{tabular}{|c|c|c|c|c|}
\hline & 1973-1983 & 1983-1990 & 1973-1990 & 1990 level \\
\hline \multicolumn{5}{|l|}{ COUNTRY } \\
\hline Australia $^{a}$ & 2.6 & 0.3 & 2.9 & 12.4 \\
\hline Austria & -3.6 & -1.7 & -5.3 & 6.4 \\
\hline Belgium & 1.1 & 0.6 & 1.7 & 12.9 \\
\hline Canada $^{a}$ & 0.9 & 0.3 & 1.2 & 7.4 \\
\hline Denmark & -0.8 & -1.3 & -2.1 & 7.2 \\
\hline Finland & 0.6 & 1.8 & 2.4 & 8.8 \\
\hline France $^{a}$ & -0.9 & -0.2 & -1.1 & 10.3 \\
\hline Germany & -1.7 & 0.3 & -1.4 & 7.7 \\
\hline Ireland & 0.6 & 2.6 & 3.2 & 13.3 \\
\hline Italy & -2.4 & 1.6 & -0.8 & 22.3 \\
\hline Japan $^{\mathrm{a}}$ & -0.8 & -1.8 & -2.6 & 11.5 \\
\hline Luxembourg & -2.3 & -1.7 & -4.0 & 7.1 \\
\hline Norway $^{a}$ & -1.0 & -0.7 & -1.7 & 6.1 \\
\hline Portugal & 4.3 & 1.5 & 5.8 & 18.5 \\
\hline Spain & 0.7 & 0.1 & 0.8 & 17.1 \\
\hline Sweden & 0.0 & 2.2 & 2.2 & 7.0 \\
\hline United Kingdom $^{\mathrm{b}}$ & 1.3 & 3.0 & 4.3 & 11.6 \\
\hline United States ${ }^{\mathrm{a}}$ & 1.0 & -0.1 & 0.9 & 7.6 \\
\hline
\end{tabular}

a) Excluding owner-managers of incorporated businesses

b) Excluding some owner-managers of incorporated businesses

Source: OECD, Labour Force Statistics, 1970-1990, Paris, 1992. 


\begin{tabular}{|c|c|c|c|c|c|c|c|c|}
\hline $\begin{array}{r}\text { NON-PRIMAR } \\
\text { IN }\end{array}$ & $\begin{array}{r}\mathrm{S} \\
\text { SELF-E } \\
\text { ISTRY }\end{array}$ & $\begin{array}{l}\text { MPLE } \\
\text { PLOYM } \\
\text { EMOGR }\end{array}$ & $\begin{array}{l}\text { ABLE } \\
\text { HARA } \\
\text { NT RA? } \\
\text { PIC G }\end{array}$ & $\begin{array}{l}\text { TERIST } \\
\text { CAND E } \\
\text { UP (MAI }\end{array}$ & $\begin{array}{l}\text { CS } \\
\text { PLOYM } \\
\text { S 1983- }\end{array}$ & $\begin{array}{l}\text { NT SHAI } \\
\text { 92) }\end{array}$ & S BY & \\
\hline & & CAI & ADA & & & NITEL & STATE & \\
\hline & & 83 & & & & & & \\
\hline Age & rate & share & rate & share & rate & share & rate & share \\
\hline $25-35$ & 11.8 & 38.9 & 12.9 & 36.9 & 9.8 & 40.1 & 8.0 & 37.2 \\
\hline $36-45$ & 18.1 & 27.6 & 19.2 & 32.4 & 15.0 & 27.0 & 14.6 & 31.6 \\
\hline $46-55$ & 20.2 & 21.2 & 22.4 & 21.0 & 17.6 & 19.4 & 18.4 & 20.3 \\
\hline $55-64$ & 19.4 & 12.3 & 25.4 & 9.7 & 18.3 & 13.5 & 19.9 & 11.0 \\
\hline Education & & & & & & & & \\
\hline $0-8$ Years & 18.3 & 16.2 & 22.0 & 7.6 & 10.8 & 7.5 & 12.6 & 4.3 \\
\hline 9-10 Years & 16.5 & 13.9 & 19.4 & 11.7 & 11.9 & 6.8 & 14.1 & 4.2 \\
\hline 11-13 Years & 15.2 & 30.5 & 16.9 & 39.5 & 11.6 & 39.7 & 11.4 & 37.3 \\
\hline Any Post Secondary & 16.1 & 39.4 & 18.3 & 41.3 & 16.6 & 46.0 & 15.0 & 54.2 \\
\hline Marital Status & & & & & & & & \\
\hline Single & 10.7 & 11.1 & 10.4 & 16.5 & 9.5 & 14.3 & 7.8 & 18.7 \\
\hline Married & 17.0 & 83.8 & 19.7 & 77.6 & 14.8 & 74.9 & 15.0 & 69.3 \\
\hline Div/Widow/Separated & 16.4 & 5.1 & 19.7 & 5.9 & 12.9 & 10.8 & 13.6 & 12.0 \\
\hline \# Children Aged $<7$ & & & & & & & & \\
\hline 0 & 17.1 & 76.5 & 17.9 & 76.3 & 14.4 & 79.0 & 13.9 & 79.8 \\
\hline 1 & 12.3 & 15.1 & 17.7 & 14.3 & 11.9 & 14.1 & 11.5 & 13.8 \\
\hline 2 & 14.9 & 7.4 & 20.5 & 8.1 & 11.2 & 6.1 & 12.9 & 5.7 \\
\hline 3 or More & 18.4 & 1.0 & 20.3 & 1.4 & 16.3 & 0.9 & 11.8 & 0.7 \\
\hline \# Children Aged 7-17 & & & & & & & & \\
\hline 0 & 15.0 & 60.1 & 17.0 & 68.1 & 13.4 & 64.5 & 13.1 & 67.8 \\
\hline 1 & 17.7 & 18.7 & 18.6 & 16.0 & 14.2 & 17.8 & 14.0 & 16.4 \\
\hline 2 & 18.3 & 15.2 & 21.9 & 12.4 & 15.3 & 12.7 & 14.8 & 11.6 \\
\hline 3 or More & 18.9 & 5.9 & 24.3 & 3.6 & 14.6 & 5.0 & 14.0 & 4.3 \\
\hline
\end{tabular}




\begin{tabular}{|c|c|c|c|c|c|c|c|c|}
\hline \multicolumn{9}{|c|}{ TABLE (2) CONTINUED } \\
\hline & \multicolumn{4}{|c|}{ CANADA } & \multicolumn{4}{|c|}{ UNITED STATES } \\
\hline & \multicolumn{2}{|c|}{1983} & \multicolumn{2}{|c|}{1992} & \multicolumn{2}{|c|}{1983} & \multicolumn{2}{|c|}{1992} \\
\hline Industry & rate & share & rate & share & rate & share & rate & share \\
\hline Manufact Non-Durable & 4.5 & 11.0 & 7.5 & 9.4 & 3.8 & 9.3 & 4.1 & 8.4 \\
\hline Manufact Durables & 5.4 & 13.7 & 4.5 & 12.7 & 3.7 & 17.6 & 4.0 & 14.4 \\
\hline Construction & 39.8 & 8.3 & 44.5 & 9.0 & 23.5 & 11.5 & 27.2 & 11.5 \\
\hline Transportation & 9.4 & 12.9 & 10.9 & 12.5 & 7.7 & 10.9 & 6.9 & 10.4 \\
\hline Wholesale Trade & 19.7 & 6.1 & 23.9 & 6.9 & 15.3 & 5.7 & 15.5 & 5.3 \\
\hline Retail Trade & 31.0 & 9.9 & 26.4 & 11.1 & 21.6 & 11.5 & 16.2 & 13.1 \\
\hline Fin/Ins./Real Estate & 18.3 & 4.7 & 23.1 & 5.0 & 20.3 & 5.3 & 18.6 & 5.3 \\
\hline Services & 22.8 & 23.6 & 23.0 & 24.9 & 21.8 & 22.3 & 19.4 & 24.8 \\
\hline Public Administration & 0.0 & 9.8 & 0.0 & 8.4 & 0.0 & 5.9 & 0.0 & 6.9 \\
\hline
\end{tabular}


TABLE (3)

Regression Results: Base Model

Linear Probability (OLS), Pooled Data

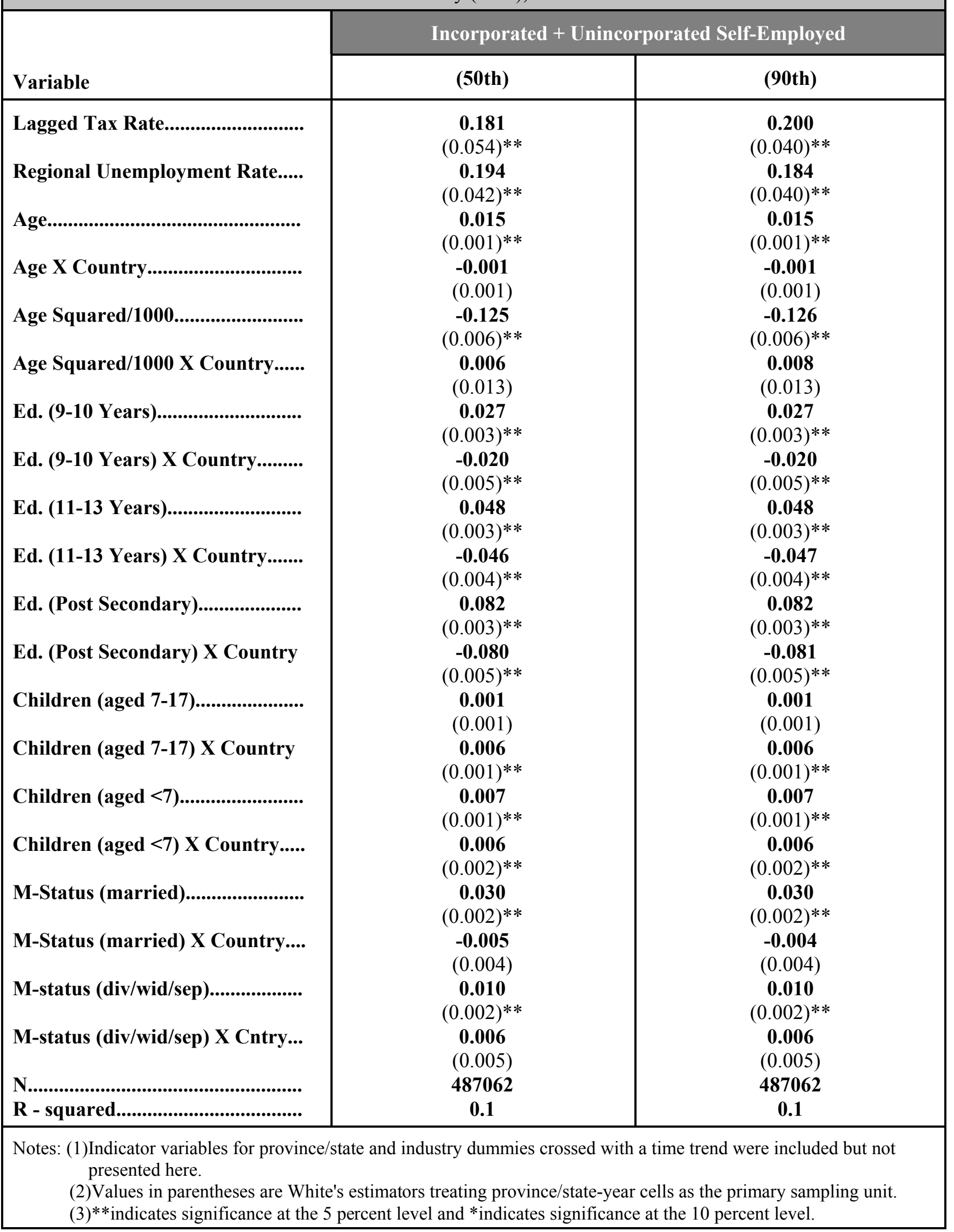




\begin{tabular}{|c|c|c|c|c|c|c|c|c|}
\hline \multicolumn{9}{|c|}{$\begin{array}{c}\text { TABLE (4) } \\
\text { Regression Results: Various Specifications } \\
\text { Linear Probability (OLS), Pooled Data } \\
\end{array}$} \\
\hline \multirow{2}{*}{ Variable } & \multicolumn{2}{|c|}{$\begin{array}{c}\text { Panel A } \\
\text { Incorp + Unincorp }\end{array}$} & \multicolumn{2}{|c|}{$\begin{array}{c}\text { Panel B } \\
\text { Incorporated Only }\end{array}$} & \multicolumn{2}{|c|}{$\begin{array}{c}\text { Panel C } \\
\text { Unincorp. Only }\end{array}$} & \multicolumn{2}{|c|}{$\begin{array}{c}\text { Panel D } \\
\text { F/T \& P/T S-E }\end{array}$} \\
\hline & (50th) & (90th) & (50th) & (90th) & (50th) & (90th) & (50th) & (90th) \\
\hline Lagged Tax & $\begin{array}{c}0.181 \\
(0.054)^{* *}\end{array}$ & $\begin{array}{c}0.200 \\
(0.040)^{* *}\end{array}$ & $\begin{array}{c}0.016 \\
(0.050)\end{array}$ & $\begin{array}{c}0.047 \\
(0.040)\end{array}$ & $\begin{array}{c}0.192 \\
(0.040)^{* *}\end{array}$ & $\begin{array}{c}0.188 \\
(0.028)^{* *}\end{array}$ & $\begin{array}{c}0.110 \\
(0.044)^{* *}\end{array}$ & $\begin{array}{c}0.133 \\
(0.037)^{* *}\end{array}$ \\
\hline $\begin{array}{l}\text { Unemployment } \\
\text { Rate }\end{array}$ & $\begin{array}{c}0.194 \\
(0.042)^{* *}\end{array}$ & $\begin{array}{c}0.184 \\
(0.040)^{* *}\end{array}$ & $\begin{array}{c}0.048 \\
(0.033)\end{array}$ & $\begin{array}{c}0.042 \\
(0.033)\end{array}$ & $\begin{array}{c}0.184 \\
(0.037)^{* *}\end{array}$ & $\begin{array}{c}0.177 \\
(0.035)^{* *}\end{array}$ & $\begin{array}{c}0.130 \\
(0.044)^{* *}\end{array}$ & $\begin{array}{c}0.130 \\
(0.044) * *\end{array}$ \\
\hline $\mathrm{N}$ & 487062 & 487062 & 441154 & 441154 & 460090 & 460090 & 450867 & 450867 \\
\hline $\mathrm{R}$ - squared & 0.10 & 0.10 & 0.06 & 0.06 & 0.07 & 0.07 & 0.06 & 0.06 \\
\hline $\begin{array}{l}\text { Notes: (1)Indicator } \\
\text { (2)Values in } \\
\text { (3)**indicat }\end{array}$ & $\begin{array}{l}\text { ables for prov } \\
\text { entheses are } V \\
\text { gnificance at }\end{array}$ & $\begin{array}{l}\text { state and ind } \\
\text { e's estimators } \\
\text { percent level }\end{array}$ & $\begin{array}{l}\text { dummies cro } \\
\text { ng province/ } \\
\text { *indicates si }\end{array}$ & $\begin{array}{l}\text { ith a time t } \\
\text { ear cells as } \\
\text { nce at the } 1\end{array}$ & $\begin{array}{l}\text { vere included } \\
\text { imary samplin } \\
\text { cent level. }\end{array}$ & $\begin{array}{l}\text { ot presented } h \\
\text { it }\end{array}$ & & \\
\hline
\end{tabular}


TABLE (5)

Lagged Tax Rate Crossed with Education and Industry Indicators

Incorporated + Unincorporated Self-Employed

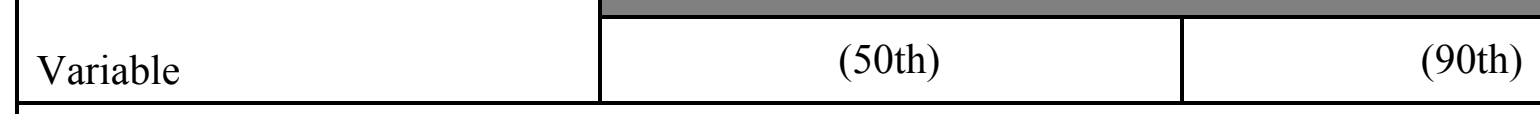

Tax Crossed With Education

\begin{tabular}{|l|c|c|}
\hline Lagged Tax & $\begin{array}{c}0.125 \\
(0.103)\end{array}$ & $\begin{array}{c}0.121 \\
(0.074)^{*}\end{array}$ \\
\hline Lagged Tax X & -0.020 & -0.003 \\
Ed. (9-10 Years) & $(0.095)$ & $(0.076)$ \\
\hline Lagged Tax X & -0.003 & 0.033 \\
Ed. (11-13 Years) & $(0.089)$ & $(0.065)$ \\
\hline Lagged Tax X & 0.125 & 0.145 \\
Ed. (Post Secondary) & $(0.097)$ & $(0.071)^{* *}$ \\
\hline Unemployment Rate & 0.195 & 0.185 \\
& $(0.042)^{* *}$ & $(0.040)^{* *}$ \\
\hline R - squared & 0.10 & 0.10 \\
\hline
\end{tabular}

Tax Rate Crossed With Industry

\begin{tabular}{|l|c|c|}
\hline Lagged Tax X & $\begin{array}{c}0.095 \\
\text { Manufacturing Non-Durables }\end{array}$ & $\begin{array}{c}-0.072 \\
(0.037)^{*}\end{array}$ \\
\hline Lagged Tax X & $0.057)^{*}$ & 0.003 \\
Manufacturing Durables & $(0.076)$ & $(0.062)$ \\
\hline Lagged Tax X & 0.499 & 0.727 \\
Construction & $(0.160)^{* *}$ & $(0.123)^{* *}$ \\
\hline Lagged Tax X & 0.321 & 0.284 \\
Transportation & $(0.070)^{* *}$ & $(0.053)^{* *}$ \\
\hline Lagged Tax X & 0.123 & 0.183 \\
Wholesale Trade & $(0.109)$ & $(0.088)^{* *}$ \\
\hline Lagged Tax X & 0.733 & 0.907 \\
Retail Trade & $(0.143)^{* *}$ & $(0.096)^{* *}$ \\
\hline Lagged Tax X & -0.357 & -0.122 \\
Finance/Insurance/Real Estate & $(0.127)^{* *}$ & $(0.107)$ \\
\hline Lagged Tax X & -0.046 & -0.023 \\
Services & $(0.070)$ & $(0.052)$ \\
\hline R - squared & 0.10 & 0.10 \\
\hline N & 487062 & 487062 \\
\hline Notes: (1)Regression includes the same variables as the base case (eq. 1) but the results are not presented here. \\
(2)Values in parentheses are White's estimators treating province/state-year cells as the primary sampling unit. \\
(3)** indicates significance at the 5 percent level and * indicates significance at the 10 percent level.
\end{tabular}




\begin{tabular}{|c|c|c|c|c|c|c|}
\hline \multicolumn{7}{|c|}{$\begin{array}{c}\text { TABLE (6) } \\
\text { Decomposition Results: 1983-1992, Canada, United States and Gap } \\
\text { Coefficients Taken From Pooled Data }\end{array}$} \\
\hline \multirow[t]{2}{*}{ Variable } & \multicolumn{2}{|c|}{$\begin{array}{l}\text { Panel A } \\
\text { Canada }\end{array}$} & \multicolumn{2}{|c|}{$\begin{array}{c}\text { Panel B } \\
\text { United States }\end{array}$} & \multicolumn{2}{|c|}{$\begin{array}{c}\text { Panel C } \\
\text { Gap (Canada-U.S.) }\end{array}$} \\
\hline & $\begin{array}{l}\text { Change } \\
\text { 1992-1983 }\end{array}$ & $\begin{array}{l}\text { Fraction } \\
\text { Predicted } \\
\text { Change }\end{array}$ & $\begin{array}{l}\text { Change } \\
\text { 1992-1983 }\end{array}$ & $\begin{array}{l}\text { Fraction } \\
\text { Predicted } \\
\text { Change }\end{array}$ & $\begin{array}{l}\text { Change } \\
1992-1983\end{array}$ & $\begin{array}{l}\text { Fraction } \\
\text { Predicted } \\
\text { Change }\end{array}$ \\
\hline Raw Self-Employment Rate & 0.0051 & ---- & -0.0071 & ---- & 0.0122 & ---- \\
\hline Predicted Self-Employment Rate & 0.0018 & 1.00 & -0.0037 & 1.00 & 0.0055 & 1.00 \\
\hline Tax Rates & 0.0035 & 1.92 & -0.0074 & 1.99 & 0.0108 & 1.97 \\
\hline Unemployment Rates & -0.0009 & -0.52 & -0.0029 & 0.79 & 0.002 & 0.37 \\
\hline Demographics & -0.0010 & -0.56 & 0.0052 & -1.41 & -0.0062 & -1.13 \\
\hline Industry & 0.0032 & 1.79 & 0.0050 & -1.34 & -0.0018 & -0.32 \\
\hline Unexplained Portion & -0.0029 & -1.64 & -0.0036 & 0.97 & 0.0006 & 0.12 \\
\hline \multicolumn{7}{|c|}{ Breakdown of Demographics } \\
\hline Age & 0.0016 & 0.88 & 0.0021 & -0.57 & -0.0005 & -0.10 \\
\hline Education & 0.0002 & 0.12 & 0.0045 & -1.21 & -0.0043 & -0.78 \\
\hline \# Children & -0.0008 & -0.46 & -0.0001 & 0.04 & -0.0007 & -0.12 \\
\hline Marital Status & -0.0007 & -0.39 & -0.0013 & 0.35 & 0.0007 & 0.12 \\
\hline Province & -0.0013 & -0.71 & -0.0001 & 0.03 & -0.0014 & -0.25 \\
\hline
\end{tabular}




\begin{tabular}{|c|c|c|c|c|}
\hline \multicolumn{5}{|c|}{$\begin{array}{c}\text { TABLE (A1) } \\
\text { Various Specifications For Illustration } \\
\text { Self-Employment Indicator as Dependent Variable Linear Probability (OLS), Pooled Data }\end{array}$} \\
\hline \multirow[b]{2}{*}{ Variable } & \multicolumn{2}{|c|}{ Including Current \& Lagged Tax/U-Rate } & \multicolumn{2}{|c|}{ Males Aged 25-54 } \\
\hline & (50th) & (90th) & (50th) & (90th) \\
\hline 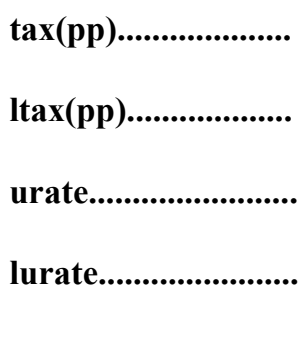 & $\begin{array}{c}\mathbf{- 0 . 0 2 5} \\
(0.073) \\
\mathbf{0 . 1 5 7} \\
(0.060) \\
\mathbf{0 . 1 5 1} \\
(0.053) \\
\mathbf{0 . 0 4 5} \\
(0.066)\end{array}$ & $\begin{array}{c}\mathbf{- 0 . 0 8 4} \\
(0.074) \\
\mathbf{0 . 2 2 9} \\
(0.061) \\
\mathbf{0 . 1 6 9} \\
(0.052) \\
\mathbf{0 . 0 1 0} \\
(0.064)\end{array}$ & $\begin{array}{c}\mathbf{0 . 1 4 8} \\
(0.055) \\
\cdots \cdots \\
\\
\mathbf{0 . 2 0 4} \\
(0.040) \\
\ldots \ldots\end{array}$ & $\begin{array}{c}\mathbf{0 . 1 6 3} \\
(0.041) \\
\ldots \ldots \\
\\
\mathbf{0 . 1 9 5} \\
(0.039) \\
\ldots \ldots\end{array}$ \\
\hline $\mathbf{N}$ & 439609 & 439609 & 424814 & 424814 \\
\hline R - squared & 0.10 & 0.10 & 0.10 & 0.10 \\
\hline
\end{tabular}




\begin{tabular}{|c|c|c|c|c|c|c|c|c|}
\hline \multicolumn{9}{|c|}{$\begin{array}{c}\text { TABLE (A2) } \\
\text { Regression Results: Table (5) Continued } \\
\text { Self-Employment Indicator as Dependent Variable Linear Probability (OLS), Pooled Data }\end{array}$} \\
\hline \multirow[b]{2}{*}{ Variable } & \multicolumn{2}{|c|}{ Incorp + Unincorp } & \multicolumn{2}{|c|}{ Incorporated Only } & \multicolumn{2}{|c|}{ Unincorp. Only } & \multicolumn{2}{|c|}{ F/T \& P/T S-E } \\
\hline & (50th) & (90th) & (50th) & (90th) & (50th) & (90th) & (50th) & (90th) \\
\hline $\operatorname{ltax}(p p) \ldots . . . . . .$. & 0.181 & 0.200 & 0.016 & 0.047 & 0.192 & 0.188 & 0.110 & 0.133 \\
\hline & $(0.054)$ & $(0.040)$ & $(0.050)$ & $(0.040)$ & $(0.040)$ & $(0.028)$ & $(0.044)$ & $(0.037)$ \\
\hline urate................ & $\begin{array}{c}\mathbf{0 . 1 9 4} \\
(0.042)\end{array}$ & $\begin{array}{c}\mathbf{0 . 1 8 4} \\
(0.040)\end{array}$ & $\begin{array}{c}\mathbf{0 . 0 4 8} \\
(0.033)\end{array}$ & $\begin{array}{c}\mathbf{0 . 0 4 2} \\
(0.033)\end{array}$ & $\begin{array}{c}\mathbf{0 . 1 8 4} \\
(0.037)\end{array}$ & $\begin{array}{c}\mathbf{0 . 1 7 7} \\
(0.035)\end{array}$ & $\begin{array}{c}\mathbf{0 . 1 3 0} \\
(0.044)\end{array}$ & $\begin{array}{c}\mathbf{0 . 1 2 9} \\
(0.044)\end{array}$ \\
\hline Manuf. Dur & 0.002 & 0.001 & -0.001 & -0.001 & 0.003 & 0.002 & -0.001 & -0.002 \\
\hline & $(0.007)$ & $(0.007)$ & $(0.004)$ & $(0.004)$ & $(0.006)$ & $(0.006)$ & $(0.005)$ & $(0.005)$ \\
\hline Construction. & $\mathbf{0 . 2 5 1}$ & $\mathbf{0 . 2 5 0}$ & $\mathbf{0 . 0 9 3}$ & $\mathbf{0 . 0 9 2}$ & $\begin{array}{c}\mathbf{0 . 2 0 4} \\
0\end{array}$ & $\mathbf{0 . 2 0 3}$ & $\begin{array}{c}\mathbf{0 . 1 7 9} \\
0\end{array}$ & $\mathbf{0 . 1 7 9}$ \\
\hline Transport....... & $\begin{array}{c}\mathbf{0 . 0 4 0} \\
(0.008)\end{array}$ & $\begin{array}{c}\mathbf{0 . 0 4 1} \\
(0.008)\end{array}$ & $\begin{array}{l}\mathbf{- 0 . 0 0 8} \\
(0.005)\end{array}$ & $\begin{array}{l}\mathbf{- 0 . 0 0 7} \\
(0.005)\end{array}$ & $\begin{array}{c}\mathbf{0 . 0 4 8} \\
(0.007)\end{array}$ & $\begin{array}{c}\mathbf{0 . 0 4 8} \\
(0.007)\end{array}$ & $\begin{array}{c}\mathbf{0 . 0 5 2} \\
(0.010)\end{array}$ & $\begin{array}{c}\mathbf{0 . 0 5 2} \\
(0.010)\end{array}$ \\
\hline Whole.Trade & $\begin{array}{c}\mathbf{0 . 1 1 2} \\
(0.013)\end{array}$ & $\begin{array}{c}\mathbf{0 . 1 1 2} \\
(0.012)\end{array}$ & $\begin{array}{c}\mathbf{0 . 0 5 7} \\
(0.009)\end{array}$ & $\begin{array}{c}\mathbf{0 . 0 5 7} \\
(0.009)\end{array}$ & $\begin{array}{c}\mathbf{0 . 0 6 9} \\
(0.009)\end{array}$ & $\begin{array}{c}\mathbf{0 . 0 6 9} \\
(0.009)\end{array}$ & $\begin{array}{c}\mathbf{0 . 0 3 5} \\
(0.007)\end{array}$ & $\begin{array}{c}\mathbf{0 . 0 3 5} \\
(0.007)\end{array}$ \\
\hline Retail Trade.. & $\begin{array}{c}\mathbf{0 . 2 3 0} \\
(0.016)\end{array}$ & $\begin{array}{c}\mathbf{0 . 2 3 0} \\
(0.016)\end{array}$ & $\begin{array}{c}\mathbf{0 . 1 1 1} \\
(0.013)\end{array}$ & $\begin{array}{c}\mathbf{0 . 1 1 1} \\
(0.013)\end{array}$ & $\begin{array}{c}\mathbf{0 . 1 6 4} \\
(0.012)\end{array}$ & $\begin{array}{c}\mathbf{0 . 1 6 4} \\
(0.012)\end{array}$ & $\begin{array}{c}\mathbf{0 . 1 1 5} \\
(0.009)\end{array}$ & $\begin{array}{c}\mathbf{0 . 1 1 5} \\
(0.009)\end{array}$ \\
\hline Fin/Ins/RealE & $\begin{array}{c}\mathbf{0 . 1 4 9} \\
(0.016)\end{array}$ & $\begin{array}{c}\mathbf{0 . 1 4 9} \\
(0.016)\end{array}$ & $\begin{array}{c}\mathbf{0 . 0 6 5} \\
(0.012)\end{array}$ & $\begin{array}{c}\mathbf{0 . 0 6 4} \\
(0.012)\end{array}$ & $\begin{array}{c}\mathbf{0 . 1 0 6} \\
(0.016)\end{array}$ & $\begin{array}{c}\mathbf{0 . 1 0 6} \\
(0.016)\end{array}$ & $\begin{array}{c}\mathbf{0 . 1 0 2} \\
(0.014)\end{array}$ & $\begin{array}{c}\mathbf{0 . 1 0 2} \\
(0.014)\end{array}$ \\
\hline Services.......... & $\begin{array}{c}\mathbf{0 . 1 6 7} \\
(0.009)\end{array}$ & $\begin{array}{c}\mathbf{0 . 1 6 7} \\
(0.009)\end{array}$ & $\begin{array}{c}\mathbf{0 . 0 4 3} \\
(0.007)\end{array}$ & $\begin{array}{c}\mathbf{0 . 0 4 3} \\
(0.007)\end{array}$ & $\begin{array}{c}\mathbf{0 . 1 4 5} \\
(0.007)\end{array}$ & $\begin{array}{c}\mathbf{0 . 1 4 5} \\
(0.007)\end{array}$ & $\begin{array}{c}\mathbf{0 . 1 5 4} \\
(0.008)\end{array}$ & $\begin{array}{c}\mathbf{0 . 1 5 4} \\
(0.008)\end{array}$ \\
\hline Pub. Admin. & $\begin{array}{c}\mathbf{- 0 . 0 6 5} \\
(0.007)\end{array}$ & $\begin{array}{c}\mathbf{- 0 . 0 6 5} \\
(0.007)\end{array}$ & $\begin{array}{c}\mathbf{- 0 . 0 4 6} \\
(0.005)\end{array}$ & $\begin{array}{c}\mathbf{- 0 . 0 4 5} \\
(0.005)\end{array}$ & $\begin{array}{c}\mathbf{- 0 . 0 2 7} \\
(0.005)\end{array}$ & $\begin{array}{c}\mathbf{- 0 . 0 2 6} \\
(0.005)\end{array}$ & $\begin{array}{c}\mathbf{- 0 . 0 0 1} \\
(0.007)\end{array}$ & $\begin{array}{c}\mathbf{- 0 . 0 0 1} \\
(0.007)\end{array}$ \\
\hline age................... & $\begin{array}{c}\mathbf{0 . 0 1 5} \\
(0.001)\end{array}$ & $\begin{array}{c}\mathbf{0 . 0 1 5} \\
(0.001)\end{array}$ & $\begin{array}{c}\mathbf{0 . 0 0 7} \\
(0.000)\end{array}$ & $\begin{array}{c}\mathbf{0 . 0 0 7} \\
(0.000)\end{array}$ & $\begin{array}{c}\mathbf{0 . 0 1 0} \\
(0.000)\end{array}$ & $\begin{array}{c}\mathbf{0 . 0 1 0} \\
(0.000)\end{array}$ & $\begin{array}{c}\mathbf{0 . 0 1 1} \\
(0.000)\end{array}$ & $\begin{array}{c}\mathbf{0 . 0 1 1} \\
(0.000)\end{array}$ \\
\hline age $X$ country & $\begin{array}{c}\mathbf{- 0 . 0 0 1} \\
(0.001)\end{array}$ & $\begin{array}{c}\mathbf{- 0 . 0 0 1} \\
(0.001)\end{array}$ & $\begin{array}{c}\mathbf{0 . 0 0 4} \\
(0.001)\end{array}$ & $\begin{array}{c}\mathbf{0 . 0 0 4} \\
(0.001)\end{array}$ & $\begin{array}{c}\mathbf{- 0 . 0 0 4} \\
(0.001)\end{array}$ & $\begin{array}{c}\mathbf{- 0 . 0 0 4} \\
(0.001)\end{array}$ & $\begin{array}{c}\mathbf{0 . 0 0 0} \\
(0.001)\end{array}$ & $\begin{array}{c}\mathbf{0 . 0 0 0} \\
(0.001)\end{array}$ \\
\hline agesq/1000..... & $\begin{array}{c}\mathbf{- 0 . 1 2 5} \\
(0.006)\end{array}$ & $\begin{array}{c}-\mathbf{- 0 . 1 2 6} \\
(0.006)\end{array}$ & $\begin{array}{c}-\mathbf{- 0 . 0 6 1} \\
(0.000)\end{array}$ & $\begin{array}{c}\mathbf{- 0 . 0 6 1} \\
(0.000)\end{array}$ & $\begin{array}{c}\mathbf{- 0 . 0 7 9} \\
(0.001)\end{array}$ & $\begin{array}{c}\mathbf{- 0 . 0 8 0} \\
(0.001)\end{array}$ & $\begin{array}{c}-\mathbf{- 0 . 0 9 9} \\
(0.001)\end{array}$ & $\begin{array}{c}\mathbf{- 0 . 0 9 9} \\
(0.001)\end{array}$ \\
\hline agesqc/1000.... & $\begin{array}{c}\mathbf{0 . 0 0 6} \\
(0.013)\end{array}$ & $\begin{array}{c}\mathbf{0 . 0 0 8} \\
(0.013)\end{array}$ & $\begin{array}{c}\mathbf{- 0 . 0 3 3} \\
(0.001)\end{array}$ & $\begin{array}{c}\mathbf{- 0 . 0 3 2} \\
(0.001)\end{array}$ & $\begin{array}{c}\mathbf{- 0 . 0 3 6} \\
(0.001)\end{array}$ & $\begin{array}{c}\mathbf{- 0 . 0 3 7} \\
(0.001)\end{array}$ & $\begin{array}{c}\mathbf{0 . 0 0 1} \\
(0.013)\end{array}$ & $\begin{array}{c}\mathbf{0 . 0 0 1} \\
(0.013)\end{array}$ \\
\hline ed(9-10 Yrs) & $\begin{array}{c}\mathbf{0 . 0 2 7} \\
(0.003)\end{array}$ & $\begin{array}{c}\mathbf{0 . 0 2 7} \\
(0.003)\end{array}$ & $\begin{array}{c}\mathbf{0 . 0 1 1} \\
(0.002)\end{array}$ & $\begin{array}{c}\mathbf{0 . 0 1 1} \\
(0.002)\end{array}$ & $\begin{array}{c}\mathbf{0 . 0 2 1} \\
(0.003)\end{array}$ & $\begin{array}{c}\mathbf{0 . 0 2 1} \\
(0.003)\end{array}$ & $\begin{array}{c}\mathbf{0 . 0 1 8} \\
(0.003)\end{array}$ & $\begin{array}{c}\mathbf{0 . 0 1 8} \\
(0.003)\end{array}$ \\
\hline $\operatorname{ed}(9-10 y r s) X c$ & $\begin{array}{c}\mathbf{- 0 . 0 2 0} \\
(0.005)\end{array}$ & $\begin{array}{c}-\mathbf{- 0 . 0 2 0} \\
(0.005)\end{array}$ & $\begin{array}{c}\mathbf{0 . 0 0 5} \\
(0.003)\end{array}$ & $\begin{array}{c}\mathbf{0 . 0 0 5} \\
(0.003)\end{array}$ & $\begin{array}{l}\mathbf{- 0 . 0 2 5} \\
(0.005)\end{array}$ & $\begin{array}{c}\mathbf{- 0 . 0 2 5} \\
(0.005)\end{array}$ & $\begin{array}{c}\mathbf{- 0 . 0 2 0} \\
(0.005)\end{array}$ & $\begin{array}{c}\mathbf{- 0 . 0 2 0} \\
(0.005)\end{array}$ \\
\hline ed(11-13yrs)... & $\begin{array}{c}\mathbf{0 . 0 4 8} \\
(0.003)\end{array}$ & $\begin{array}{c}\mathbf{0 . 0 4 8} \\
(0.003)\end{array}$ & $\begin{array}{c}\mathbf{0 . 0 3 4} \\
(0.001)\end{array}$ & $\begin{array}{c}\mathbf{0 . 0 3 4} \\
(0.001)\end{array}$ & $\begin{array}{c}\mathbf{0 . 0 2 5} \\
(0.003)\end{array}$ & $\begin{array}{c}\mathbf{0 . 0 2 5} \\
(0.003)\end{array}$ & $\begin{array}{c}\mathbf{0 . 0 2 8} \\
(0.003)\end{array}$ & $\begin{array}{c}\mathbf{0 . 0 2 8} \\
(0.003)\end{array}$ \\
\hline ed(11-13)Xc... & $\begin{array}{c}\mathbf{- 0 . 0 4 6} \\
(0.004)\end{array}$ & $\begin{array}{c}\mathbf{- 0 . 0 4 7} \\
(0.004)\end{array}$ & $\begin{array}{c}-\mathbf{- 0 . 0 1 0} \\
(0.003)\end{array}$ & $\begin{array}{c}\mathbf{- 0 . 0 1 0} \\
(0.003)\end{array}$ & $\begin{array}{c}\mathbf{- 0 . 0 4 4} \\
(0.004)\end{array}$ & $\begin{array}{c}\mathbf{- 0 . 0 4 5} \\
(0.004)\end{array}$ & $\begin{array}{c}\mathbf{- 0 . 0 4 4} \\
(0.005)\end{array}$ & $\begin{array}{l}\mathbf{- 0 . 0 4 5} \\
(0.005)\end{array}$ \\
\hline ed(PostSec).... & $\begin{array}{c}\mathbf{0 . 0 8 2} \\
(0.003)\end{array}$ & $\begin{array}{c}\mathbf{0 . 0 8 2} \\
(0.003)\end{array}$ & $\begin{array}{c}\mathbf{0 . 0 6 9} \\
(0.002)\end{array}$ & $\begin{array}{c}\mathbf{0 . 0 6 9} \\
(0.002)\end{array}$ & $\begin{array}{c}\mathbf{0 . 0 3 2} \\
(0.003)\end{array}$ & $\begin{array}{c}\mathbf{0 . 0 3 2} \\
(0.003)\end{array}$ & $\begin{array}{c}\mathbf{0 . 0 4 2} \\
(0.003)\end{array}$ & $\begin{array}{c}\mathbf{0 . 0 4 2} \\
(0.003)\end{array}$ \\
\hline ed(PostSec)Xc & $\begin{array}{c}\mathbf{- 0 . 0 8 0} \\
(0.005)\end{array}$ & $\begin{array}{c}\mathbf{- 0 . 0 8 1} \\
(0.005)\end{array}$ & $\begin{array}{c}\mathbf{- 0 . 0 3 7} \\
(0.003)\end{array}$ & $\begin{array}{c}\mathbf{- 0 . 0 3 7} \\
(0.003)\end{array}$ & $\begin{array}{c}\mathbf{- 0 . 0 6 0} \\
(0.005)\end{array}$ & $\begin{array}{c}\mathbf{- 0 . 0 6 0} \\
(0.005)\end{array}$ & $\begin{array}{c}\mathbf{- 0 . 0 4 5} \\
(0.005)\end{array}$ & $\begin{array}{c}\mathbf{- 0 . 0 4 5} \\
(0.005)\end{array}$ \\
\hline
\end{tabular}


Table (A2) Continued

\begin{tabular}{|c|c|c|c|c|c|c|c|c|}
\hline \multirow[b]{2}{*}{ Variable } & \multicolumn{2}{|c|}{ Incorp + Unincorp } & \multicolumn{2}{|c|}{ Incorporated Only } & \multicolumn{2}{|c|}{ Unincorp. Only } & \multicolumn{2}{|c|}{ F/T \& P/T S-E } \\
\hline & (50th) & (90th) & (50th) & (90th) & (50th) & (90th) & (50th) & (90th) \\
\hline \multirow[t]{2}{*}{ \# child(7-17) } & 0.001 & 0.001 & 0.002 & 0.002 & -0.001 & -0.001 & 0.000 & 0.000 \\
\hline & $(0.001)$ & $(0.001)$ & $(0.000)$ & $(0.000)$ & $(0.001)$ & (0.001) & $(0.001)$ & $(0.001)$ \\
\hline \multirow[t]{2}{*}{$\#(7-17) X e n t r y$} & 0.006 & 0.006 & 0.004 & 0.004 & 0.004 & 0.004 & 0.009 & 0.009 \\
\hline & $(0.001)$ & $(0.001)$ & $(0.001)$ & $(0.001)$ & $(0.001)$ & $(0.001)$ & $(0.002)$ & $(0.002)$ \\
\hline \multirow[t]{2}{*}{$\#$ child $(<7) \ldots . . .}$. & 0.007 & 0.007 & 0.004 & 0.004 & 0.004 & 0.004 & 0.005 & 0.005 \\
\hline & $(0.001)$ & $(0.001)$ & $(0.001)$ & $(0.001)$ & $(0.001)$ & $(0.001)$ & $(0.001)$ & $(0.001)$ \\
\hline$\#(<7)$ Xcntry... & $\begin{array}{c}\mathbf{0 . 0 0 6} \\
(0.002)\end{array}$ & $\begin{array}{c}\mathbf{0 . 0 0 6} \\
(0.002)\end{array}$ & $\begin{array}{c}\mathbf{0 . 0 0 3} \\
(0.002)\end{array}$ & $\begin{array}{c}\mathbf{0 . 0 0 3} \\
(0.002)\end{array}$ & $\begin{array}{c}\mathbf{0 . 0 0 4} \\
(0.002)\end{array}$ & $\begin{array}{c}\mathbf{0 . 0 0 4} \\
(0.002)\end{array}$ & $\begin{array}{c}\mathbf{0 . 0 1 0} \\
(0.002)\end{array}$ & $\begin{array}{c}\mathbf{0 . 0 1 0} \\
(0.002)\end{array}$ \\
\hline married............. & $\begin{array}{c}\mathbf{0 . 0 3 0} \\
(0.002)\end{array}$ & $\begin{array}{l}\mathbf{0 . 0 3 0} \\
(0.002)\end{array}$ & $\begin{array}{c}\mathbf{0 . 0 2 0} \\
(0.001)\end{array}$ & $\begin{array}{c}\mathbf{0 . 0 2 0} \\
(0.001)\end{array}$ & $\begin{array}{c}\mathbf{0 . 0 1 5} \\
(0.001)\end{array}$ & $\begin{array}{c}\mathbf{0 . 0 1 5} \\
(0.001)\end{array}$ & $\mathbf{0 . 0 1 9}$ & $\mathbf{0 . 0 1 8}$ \\
\hline \multirow{2}{*}{ marriedXc..... } & -0.005 & -0.004 & 0.008 & 0.008 & -0.012 & -0.012 & -0.009 & -0.009 \\
\hline & $(0.004)$ & $(0.004)$ & $(0.003)$ & $(0.003)$ & $(0.003)$ & $(0.003)$ & $(0.004)$ & $(0.004)$ \\
\hline \multirow{2}{*}{ (div/wid/sep). } & $\mathbf{0 . 0 1 0}$ & $\mathbf{0 . 0 1 0}$ & $\mathbf{0 . 0 0 0}$ & $\mathbf{- 0 . 0 0 1}$ & 0.011 & $\mathbf{0 . 0 1 1}$ & 0.014 & 0.014 \\
\hline & $\begin{array}{c}(0.002) \\
\mathbf{0 . 0 0 6}\end{array}$ & $\begin{array}{c}(0.002) \\
\mathbf{0 . 0 0 6}\end{array}$ & $\begin{array}{c}(0.001) \\
\mathbf{0 . 0 0 9}\end{array}$ & $\begin{array}{c}(0.001) \\
\mathbf{0 . 0 0 9}\end{array}$ & $\begin{array}{l}(0.002) \\
-\mathbf{0 . 0 0 1}\end{array}$ & $\begin{array}{l}(0.002) \\
-\mathbf{0 . 0 0 1}\end{array}$ & $\begin{array}{c}(0.002) \\
\mathbf{0 . 0 0 0}\end{array}$ & $\begin{array}{c}(0.002) \\
0.000\end{array}$ \\
\hline $\begin{array}{l}\text { (div/wid/sep). } \\
\text { Xentry }\end{array}$ & $(0.005)$ & $(0.005)$ & $(0.003)$ & $(0.003)$ & $(0.004)$ & $(0.004)$ & $(0.006)$ & $(0.006)$ \\
\hline $\mathbf{N}$ & 487062 & 487062 & 441154 & 441154 & 460090 & 460090 & 450867 & 450867 \\
\hline R - squared & 0.10 & 0.10 & 0.06 & 0.06 & $\mathbf{0 . 0 7}$ & $\mathbf{0 . 0 7}$ & 0.06 & 0.06 \\
\hline \multicolumn{9}{|c|}{$\begin{array}{l}\text { Notes: (1)Indicator variables for province/state and industry dummies crossed with a time trend and a time trend } \\
\text { squared were included but not presented here. }\end{array}$} \\
\hline
\end{tabular}




\section{FIGURES}

Figure (1)

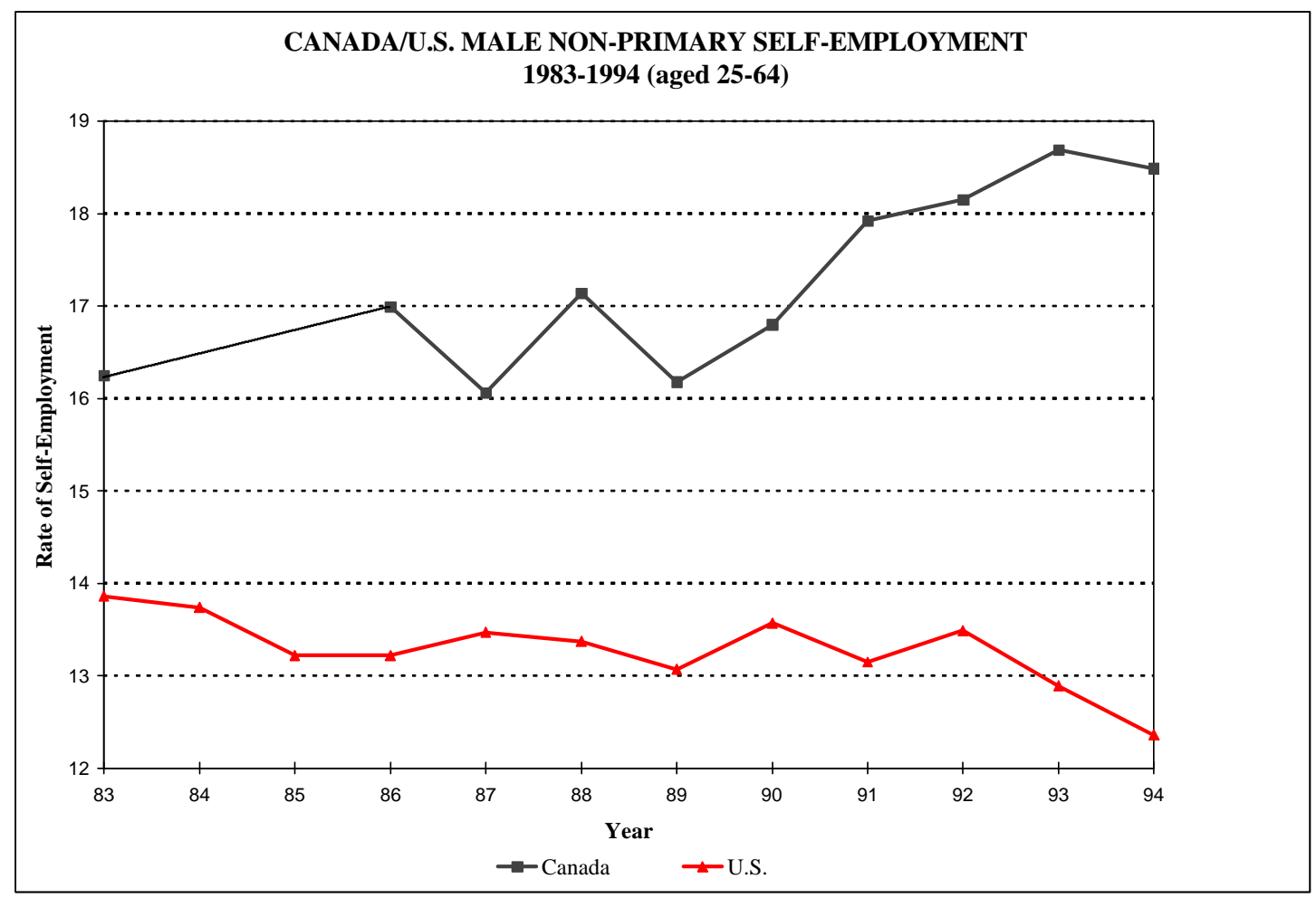

Figure (2)

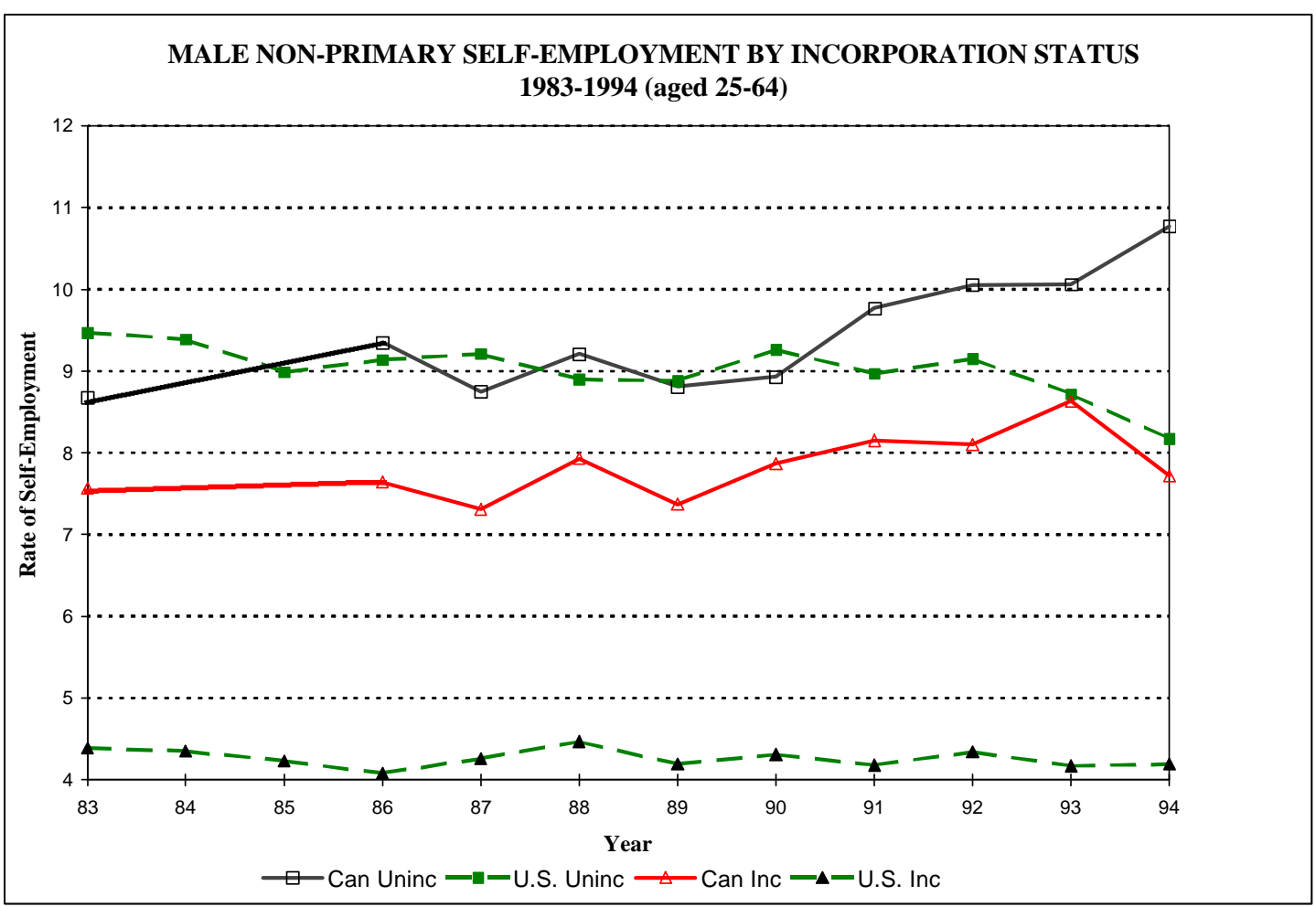


Figure (3)

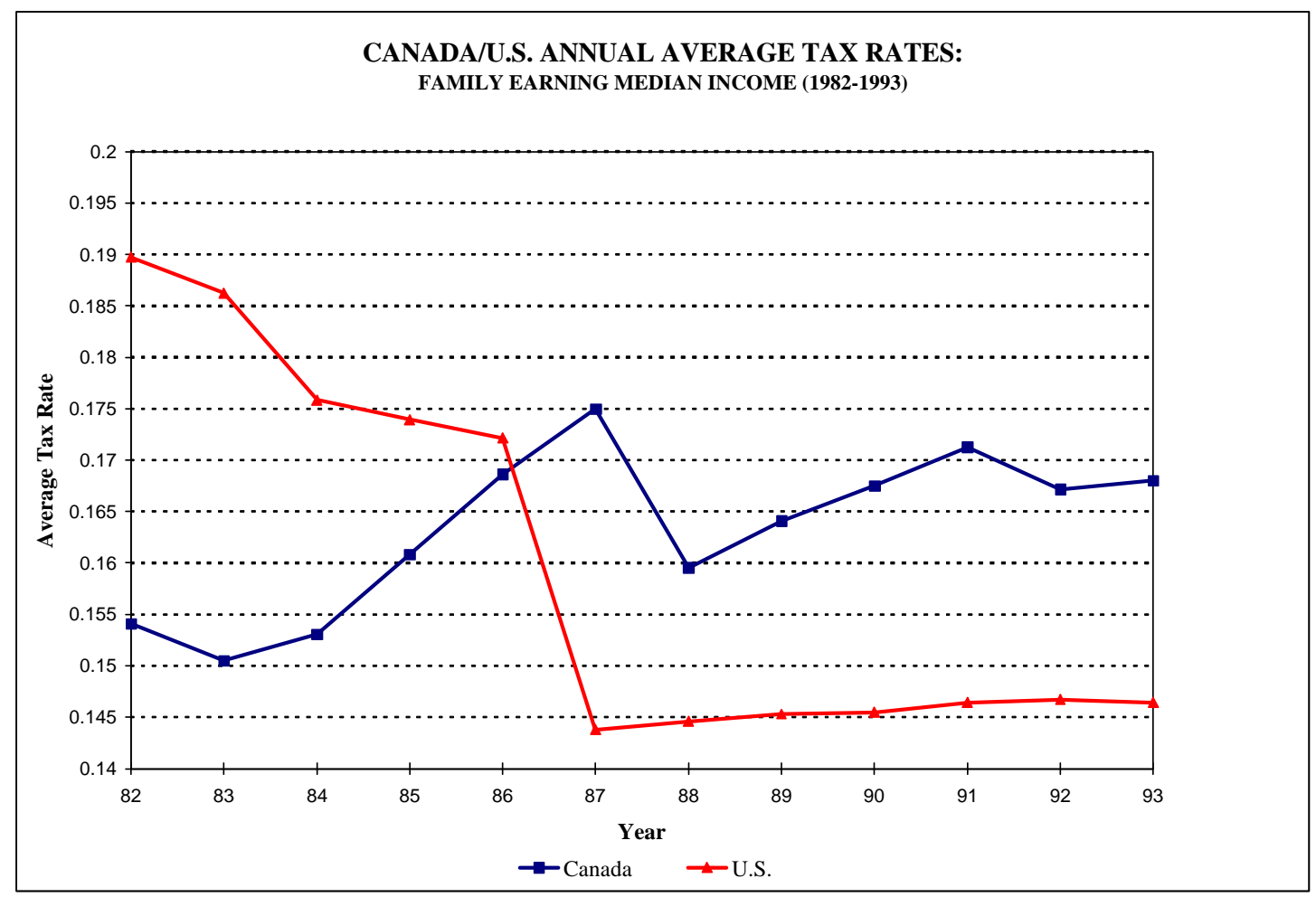

Figure (4)

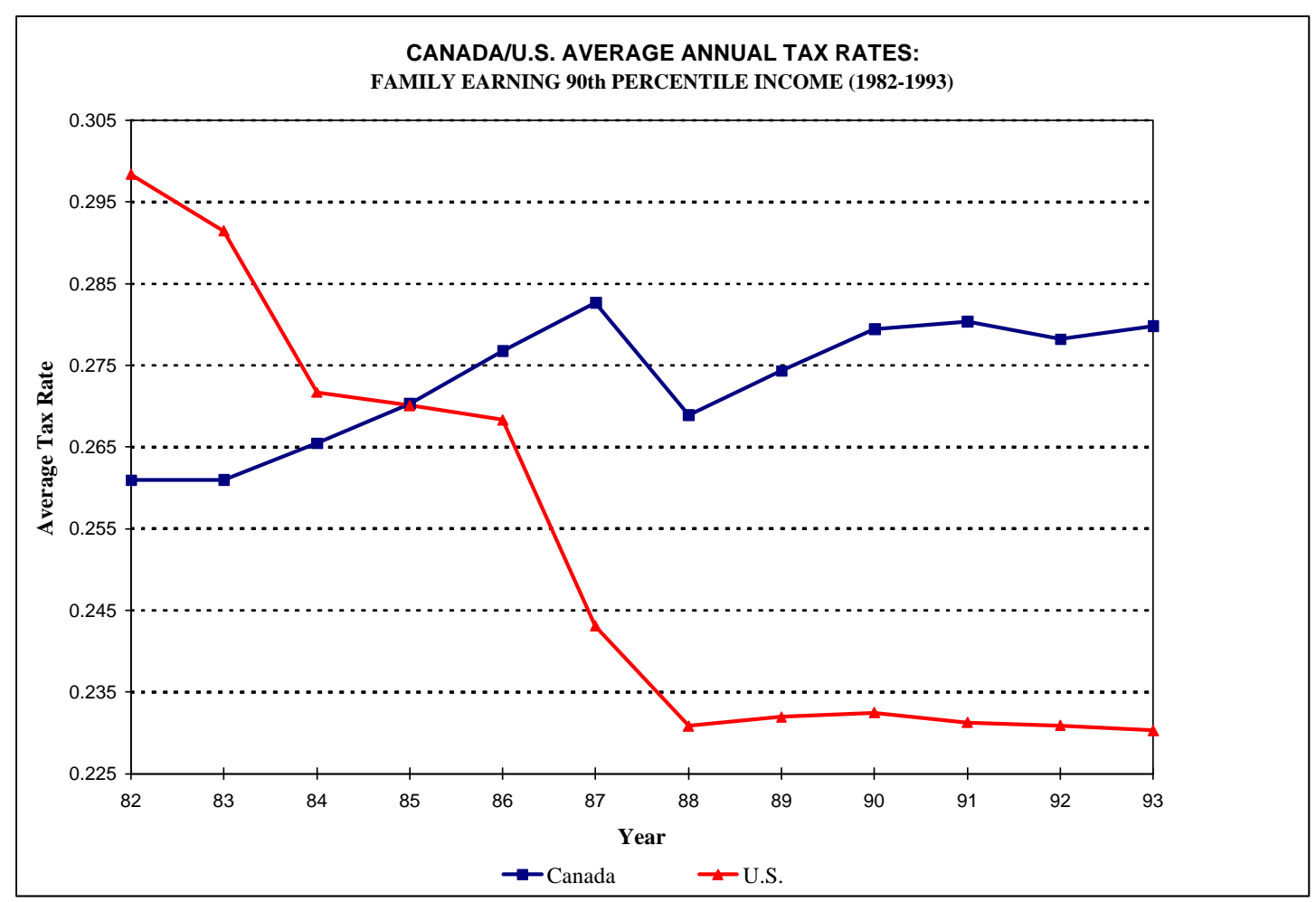


Figure (5)

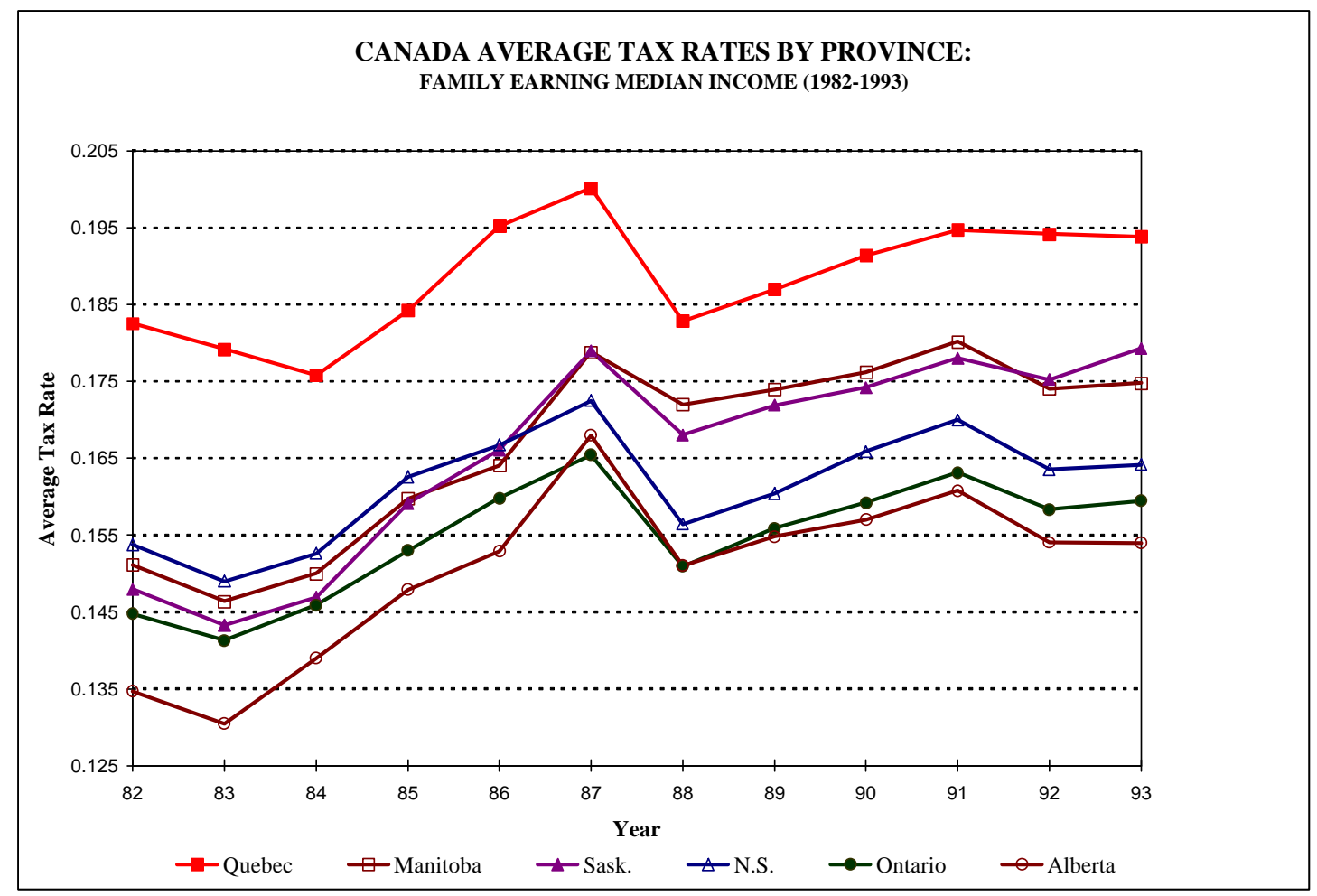

Figure (6)

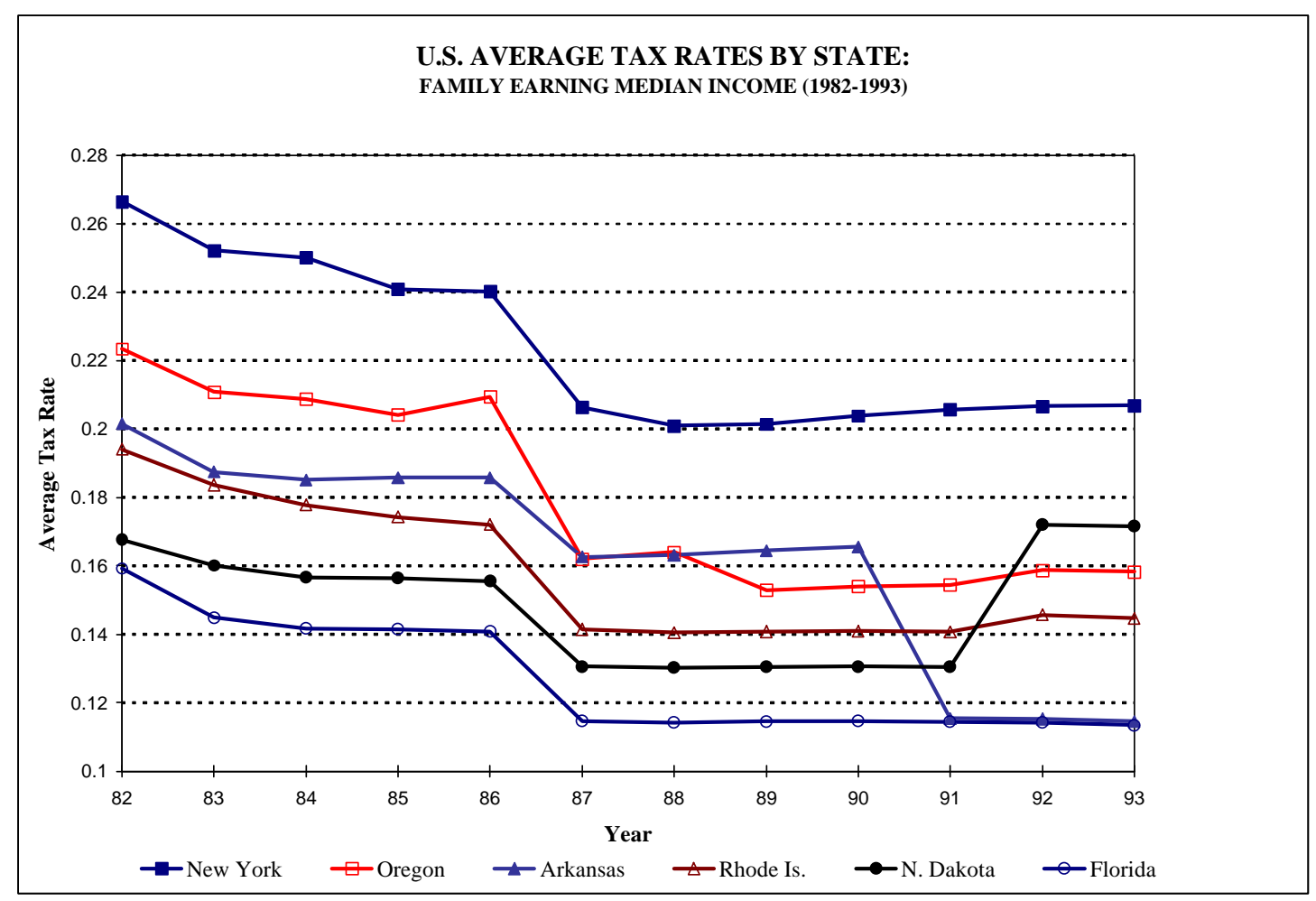


Figure (7)

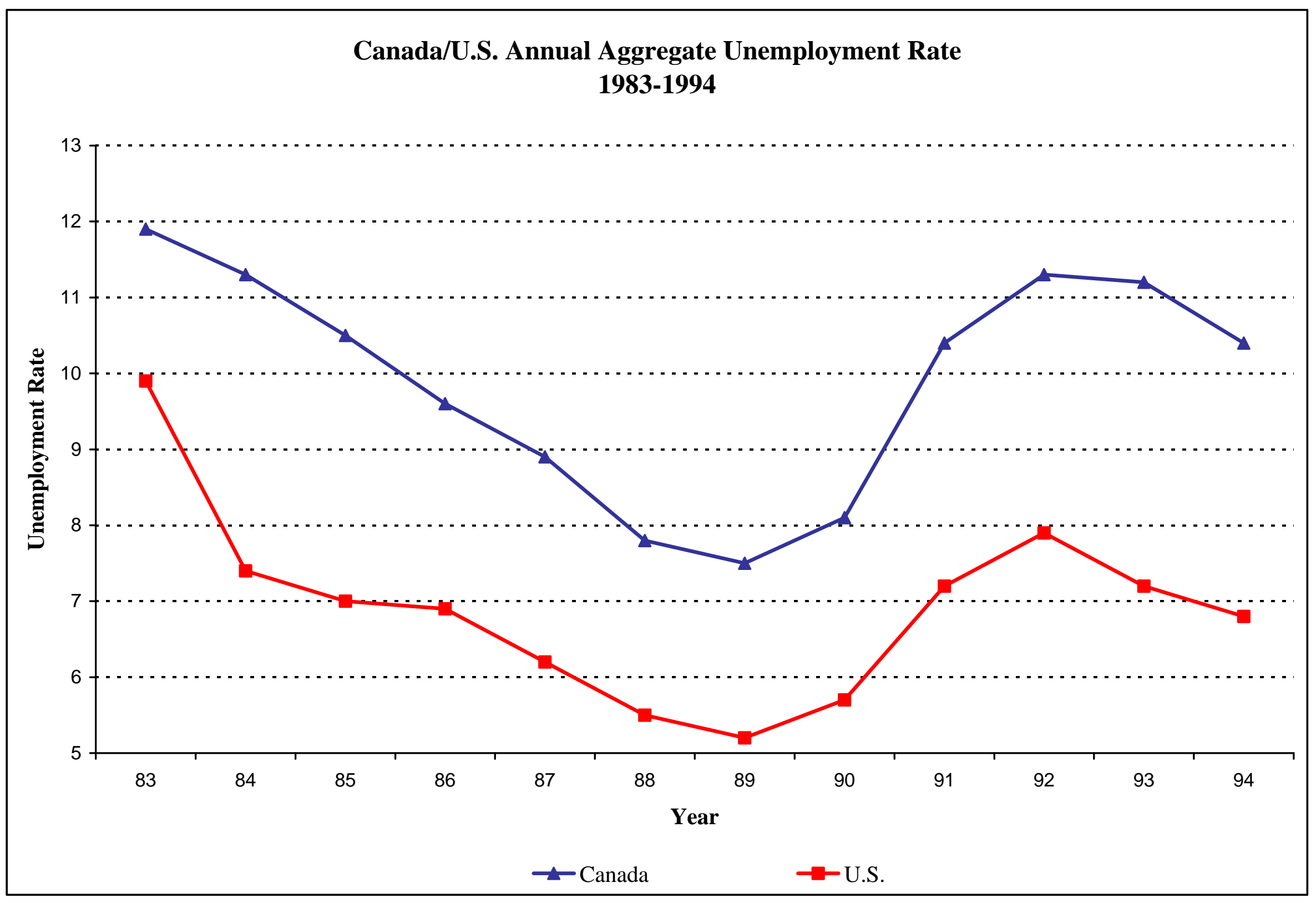


Figure (8)

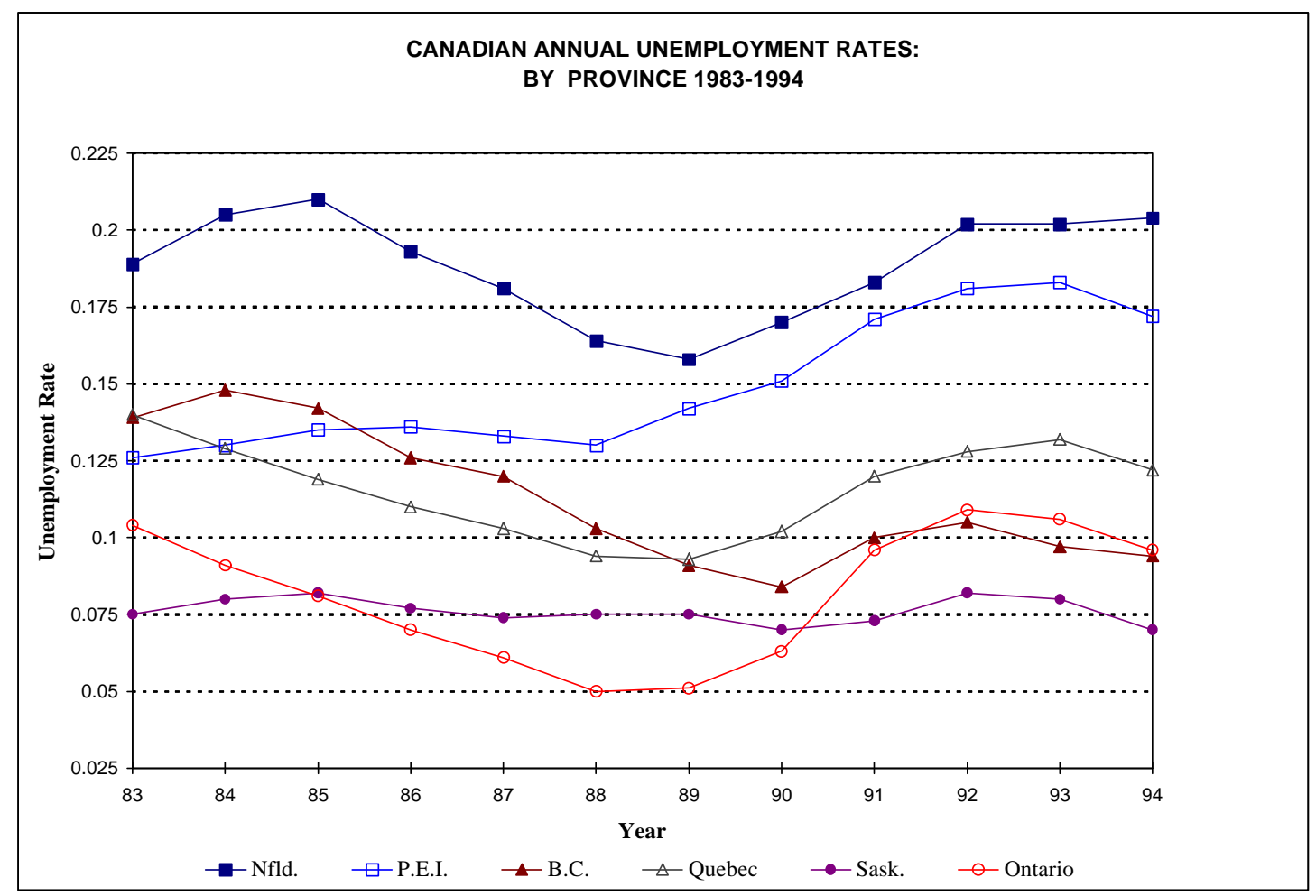

Figure (9)

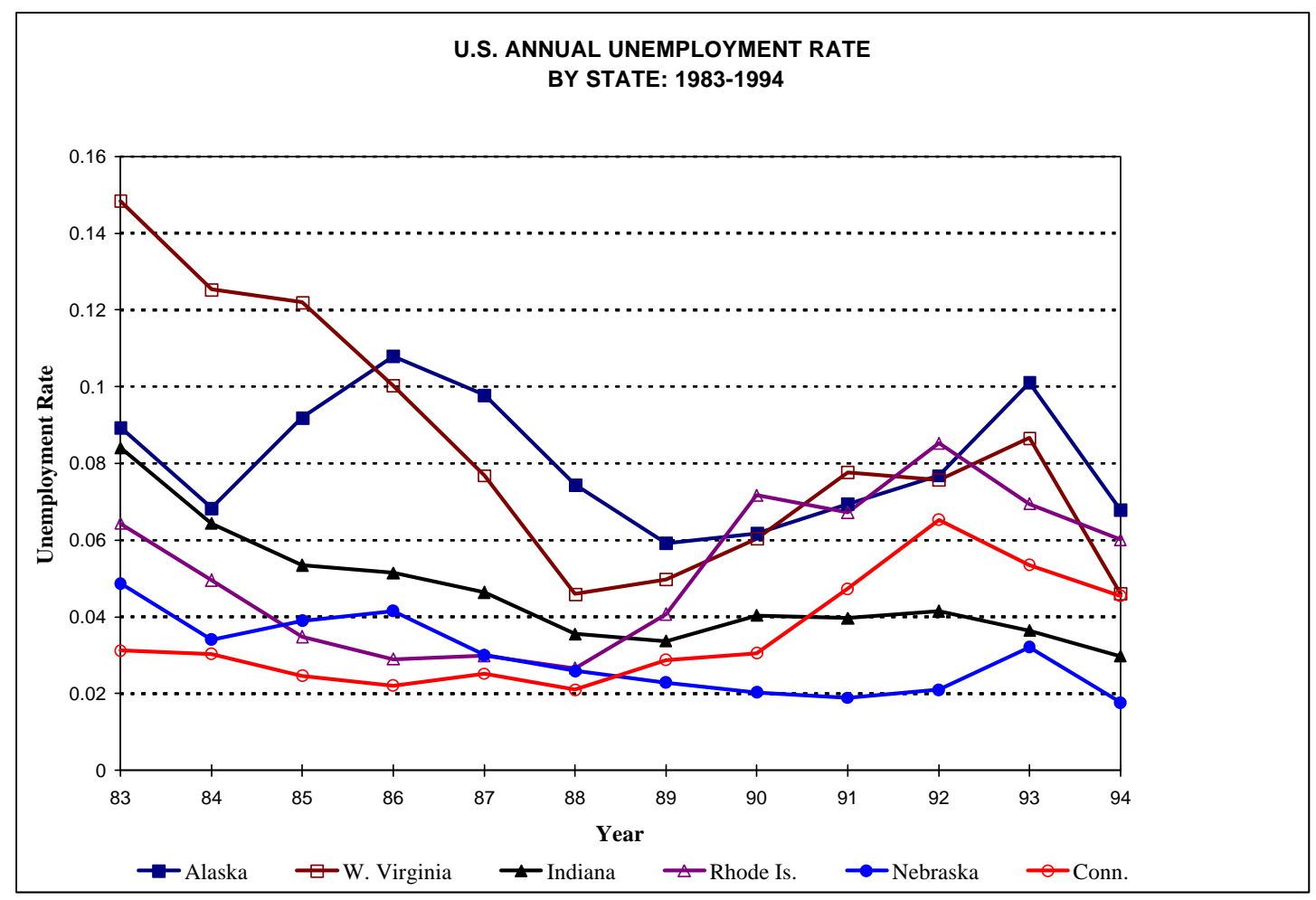




\section{Appendix}

\section{A. EMPLOYMENT STATUS QUESTIONS:}

\section{$\underline{\text { CANADA (SCF) }}$}

"In ...'s job, was he/she a paid worker, self-employed or an unpaid family worker?"

Worked for Others

1.Paid Worker (Private, Public)

2.Unpaid Family Worker

Self-Employment

Incorporated Business - with paid help

Incorporated Business - no paid help

Unincorporated Business - with paid help

Unincorporated Business (include self-employed without a business) - no paid help

$\underline{\mathrm{US}(\mathrm{CPS})}$

"What was ...'s longest job during 19..?"

Class of Worker

Paid

1. Private

2. Federal Government

3. State Government

4. Local Government

Self-Employment

1. Incorporated? $\div$ Yes

2. $\div$ No

3. Without Pay

\section{B. TAX CALCULATIONS:}

Both for Canada and the US, income is assumed to come from employment and the family is assumed to have no dependents. In Canada, the couple is assumed to file independently, deductions are taken for CPP or QPP and UI premiums and, a sales tax credit introduced in 1986 and the Goods and Service Tax credit in 1991 are reflected in the calculations. However, no provincial low income deductions, cost of living credits or sales tax credits are included in the tax calculations for Canada. In the US, the couple is assumed to file jointly and TAXSIM covers ordinary and super tax brackets, earned income credits, secondary earner deductions and other important features of the US tax code.

\section{VARIABLE DESCRIPTION:}


Industry Indicators: manufacturing non-durables (omitted industry), manufacturing durables, construction, transportation/communication, wholesale trade, retail trade, finance/insurance/realestate, services and public administration

Demographic Variables: The demographic variables include age, age squared, dummy variables for education (0-8 years (omitted group), 9-10 years, 11-13 years and any post secondary), number of young children (aged less than 7), number of older children (aged 7 to 17), and dummy variables for marital status (single (omitted group), married and divorced/widowed or separated).

Region: The regions include the 10 provinces in Canada and the 50 states and the District of Columbia in the United States. The omitted region is Alabama.

Time and Time Squared: time and timesq are the time trend and the time trend squared for the omitted industry. 


\section{References}

Aronson, Robert L. (1991) Self-Employment ILR Press, Ithaca, New York

Becker, Eugene, (1984) "Self-Employed Workers: An Update to 1983", Monthly Labor Review 107 pp. $14-18$

Bishop, John H., (1987) "American Job Growth: What Explains It?", Portfolio: International Economic Perspectives 12

Blanchflower, D. and Oswald, A., (1990) "Self-Employment and the Enterprise Culture", in British Social Attitudes: the 1990 Report, edited by R. Jowell, S. Witherspoon and L. Brook, Gower.

Blau, David (1987) "A Time Series Analysis of Self-Employment in the United States", Journal of Political Economy, Vol 95, no.3, pp. 445-467

Borjas, George J., and Stephen G. Bronars (1989) "Consumer Discrimination and SelfEmployment", Journal of Political Economy 97 pp. 581-605

Canadian Tax Foundation (1982-1993) The National Finances: An Analysis of the Revenues and Expenditures of the Government of Canada Canadian Tax Foundation Publications, Toronto

Crompton, Susan (1993) "The Renaissance of Self-Employment" Perspectives on Income and Employment Statistics Canada Cat. 75-001E, pp. 22-32

Devine, Theresa (1993) "The Recent Rise in U.S. Self-Employment", mimeo, The Pennsylvania State University

Devine, Theresa (1990) "The Recent Rise in Female Self-Employment", mimeo, The Pennsylvania State University

Devine, Theresa and Joyce Mlakar (1993) "Inter-Industry Variation in the Determinants of Self-Employment", mimeo, The Pennsylvania State University

Erard, Brian (1997) "A Critical Review of the Empirical Research on Canadian Tax Compliance" Working Paper 97-6, Business Income Tax Division Department of Finance Canada.

Evans, David S., and Linda S. Leighton (1989) "Some Empirical Aspects of Entrepreneurship", American Economic Review, vol. 79, pp. 519-535

Feenberg, Daniel Richard, and Elizabeth Coutts (1993) "An Introduction to the TAXSIM Model", Journal of Policy Analysis and Management, vol. 12 no. 1, pp. 189-194. 
Iams, Howard M. (1987) "Jobs of Persons Working After Receiving Retired Work Benefits", Social Security Bulletin 50 (November) pp. 4-19

Lin, Zhengxi, Janice Yates and Garnett Picot (1998) Rising Self-Employment in the Midst of High Unemployment: An Empirical Analysis of Recent Developments in Canada", Working Paper, Business and Labour Market Analysis Division Statistics Canada.

Long, James E. (1982) "The Income Tax and Self-Employment", National Tax Journal. 35 (March): pp. 31-42.

Moulton, Brent R., (1990) "An Illustration of a Pitfall in Estimating the Effects of Aggregate Variables on Micro Units", The Review of Economics and Statistics, 72(2), pp. 334-338.

OECD (1992) Employment Outlook: July 1992, OECD Publication, Paris

Parnes, Herbert S., and Lawrence J. Less. (1985) "Economic Well-Being in Retirement." in Retirement Among American Men, ed. Herbert S. Parnes, pp. 91-118. Lexington, Mass.: Lexington Books.

Quinn, Joseph F., (1980) "Labor Force Participation Patterns of Older Self-Employed Workers", Social Security Bulletin 43 pp. 17-28

Rees, Hedley, and Shah, Anup, (1986) "An Empirical Analysis of Self-Employment in the U.K.", Journal of Applied Econometrics 1 pp. $95-108$

U.S. Internal Revenue Service (1990) "Income Tax Compliance Research: Net Tax Gap and Remittance Gap Estimates", Publication 1415, Washington, D.C.

White, H., (1980) "A Heteroskedasticity-Consistent Covariance Matrix Estimator and a Direct Test for Heteroskedasticity." Econometrica 48 pp. 817-830 